
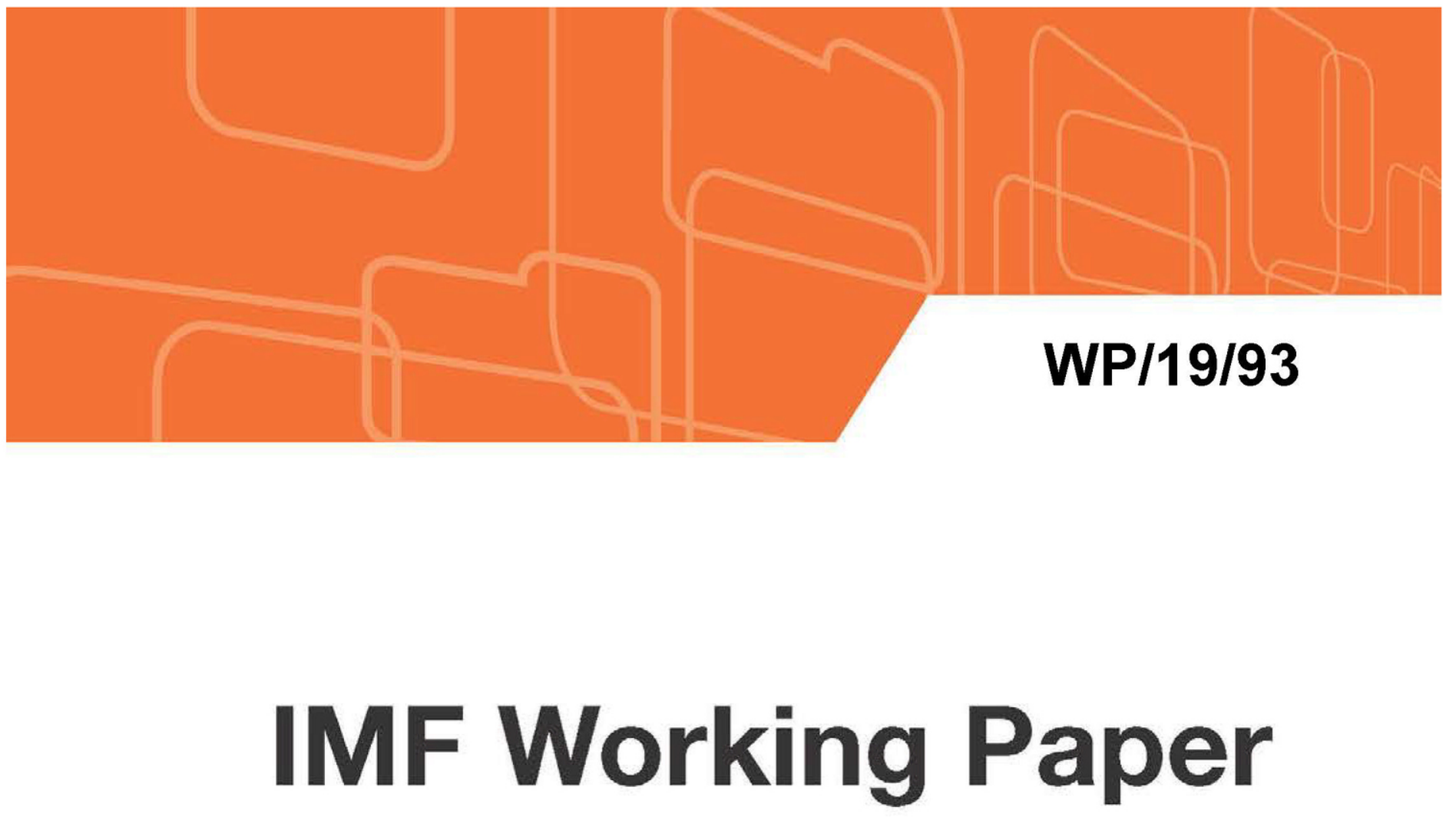

\title{
The Turning Tide: How Vulnerable are Asian Corporates?
}

by Bo Jiang and Tahsin Saadi Sedik

IMF Working Papers describe research in progress by the author(s) and are published to elicit comments and to encourage debate. The views expressed in IMF Working Papers are those of the author(s) and do not necessarily represent the views of the IMF, its Executive Board, or IMF management. 


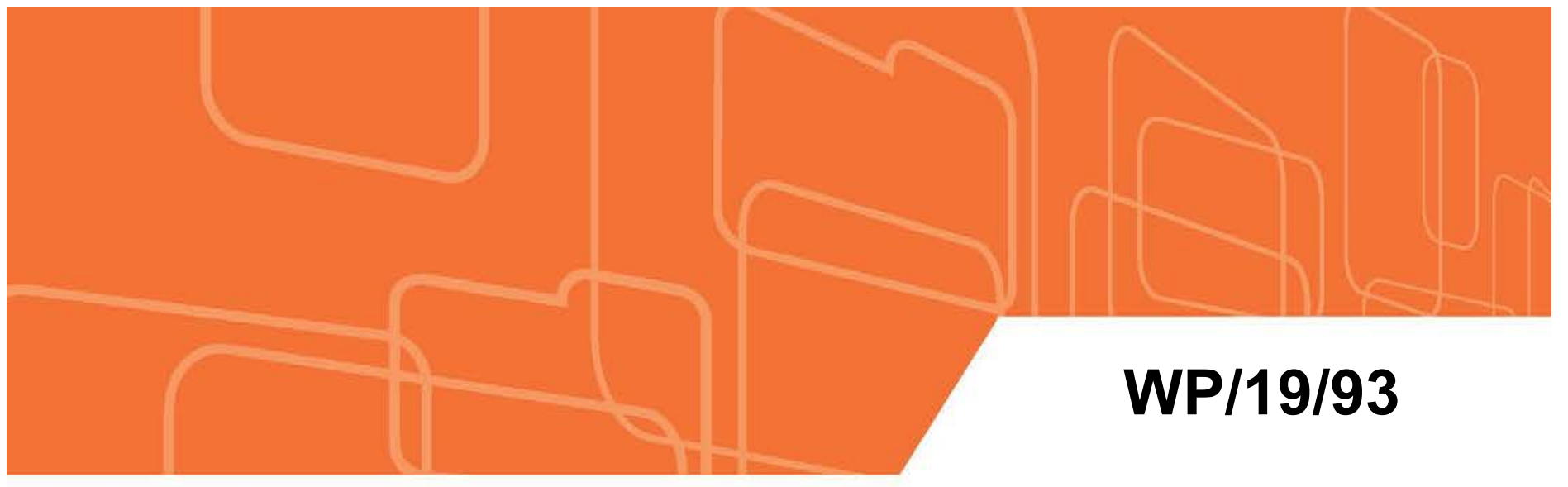

\section{IMF Working Paper}

\section{The Turning Tide: How Vulnerable are Asian Corporates?}

by Bo Jiang and Tahsin Saadi Sedik

IMF Working Papers describe research in progress by the author(s) and are published to elicit comments and to encourage debate. The views expressed in IMF Working Papers are those of the author(s) and do not necessarily represent the views of the IMF, its Executive Board, or IMF management. 


\title{
IMF Working Paper
}

Asia and Pacific Department

The Turning Tide: How Vulnerable are Asian Corporates?

Prepared by Bo Jiang and Tahsin Saadi Sedik ${ }^{1}$

Authorized for distribution by Koshy Mathai

May 2019

IMF Working Papers describe research in progress by the author(s) and are published to elicit comments and to encourage debate. The views expressed in IMF Working Papers are those of the author(s) and do not necessarily represent the views of the IMF, its Executive Board, or IMF management.

\begin{abstract}
Using a new firm-level dataset with comprehensive information on Asian firms' FX liabilities, we show that Asia's nonfinancial corporate sector is vulnerable to a tightening of global financial conditions. Higher global interest rates and exchange rate depreciation increase the probability of default of Asian firms. A 30 percent currency depreciation is associated with a two-notch downgrade in the corporate credit rating (e.g., from $\mathrm{A}$ to $\mathrm{BBB}+$ ), resulting in 7 percent of Asian firms falling into bankruptcy. But the impact is nonlinear-as the firms' FX liability increases, the balance sheet channel of exchange rate offsets, then dominates, the competitiveness channel. The balance sheet channel offsets the competitiveness channel when the share of U.S. dollar debt is between 10 and 20 percent. We also find that currency depreciation increases firm-level investment on average, but for firms with the share of FX liabilities above 20 percent, investment contracts with depreciation.
\end{abstract}

JEL Classification Numbers: F31, F41, F43, G01, G10, G15, G30, G31.

Keywords: Asian Emerging Markets, Corporate Debt, Corporate Distress, Global Finacnial Conditions, Exchange Rate Depreciation.

Author's E-Mail Address: sheilajb@uchicago.edu; tsaadisedik@imf.org

\footnotetext{
${ }^{1}$ We are grateful for helpful comments from Zhiguo He, Pablo Lopez Murphy, Koshy Mathai, Jonathan Ostry, Jay Peiris, Raghuram Rajan, and Amir Sufi. This paper also benefitted from comments by seminar participants at IMF's Asia and Pacific Department, and Finance Brownbag at Chicago Booth and Capital Theory Working Group of University of Chicago Department of Economics. Any errors and omissions are our own responsibility.
} 


\section{CONTENTS}

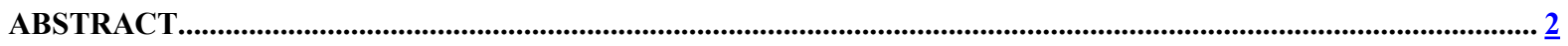

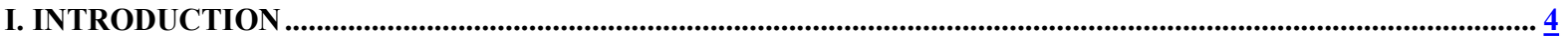

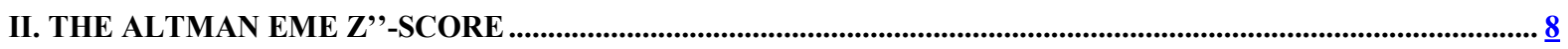

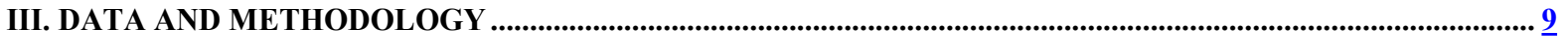

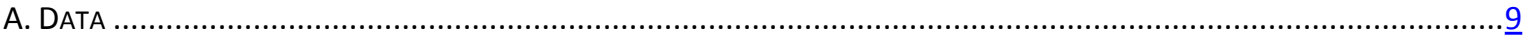

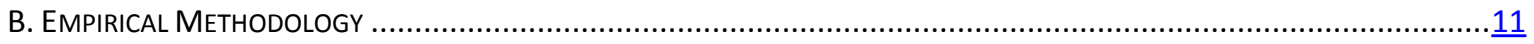

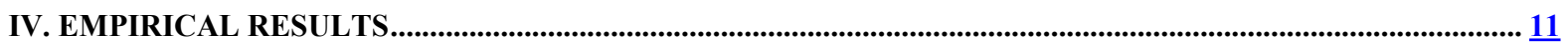

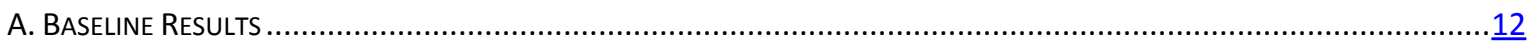

B. Corporate Vulnerability: Competitiveness vs. Financial Channels of the ExChange Rate...............................13

C. Corporate InVestment: Competitiveness vs. Financial Channels of the Exchange Rate ................................14

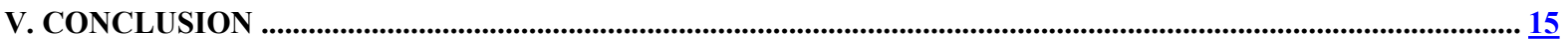

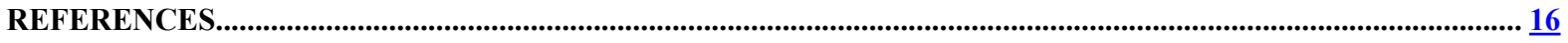

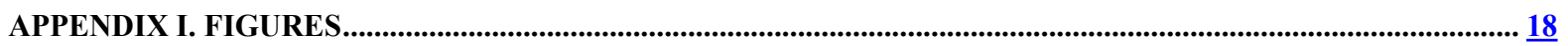

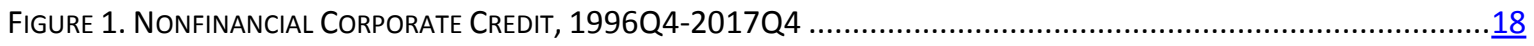

Figure 2: U.S. Monetary Policy Conditions And Cross-Border Bank Credit ..................................................19

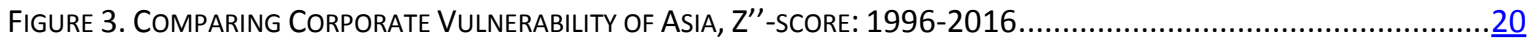

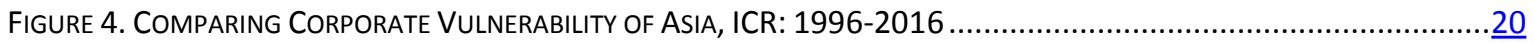

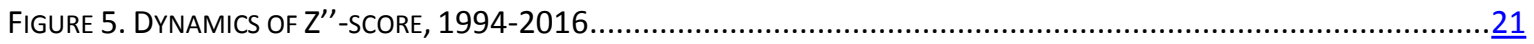

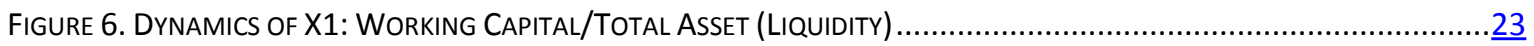

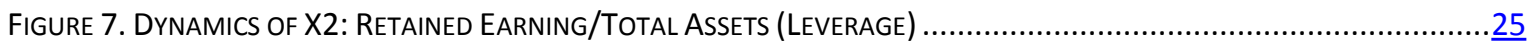

Figure 8. DYNAMICS OF X3: OPERATING INCOME/TOTAL ASSETS (PROFITABILITY) ....................................................

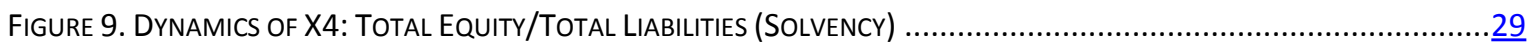

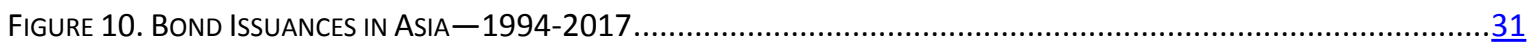

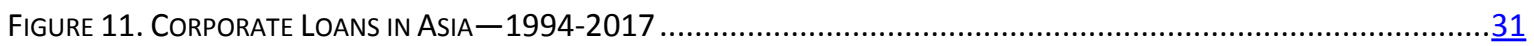

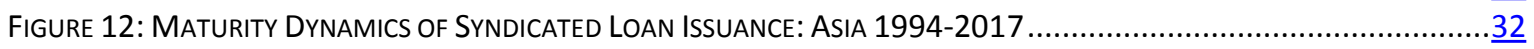

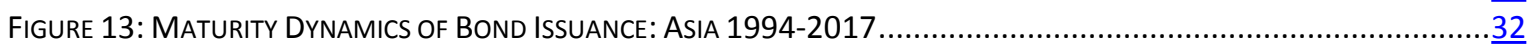

Figure 14: Distribution OF CORPORATES' U.S. DOLLAR DEBT/TOTAL ASSETS: EXPORTER/NON-EXPORTER AND TRADABLE

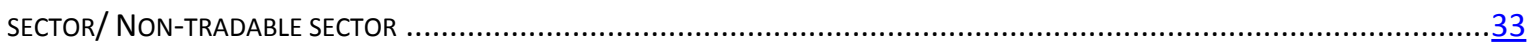

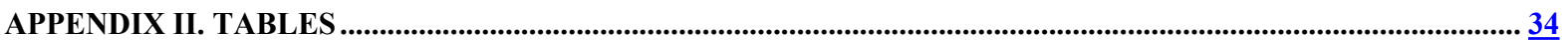

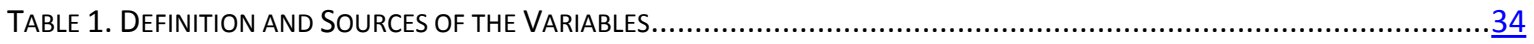

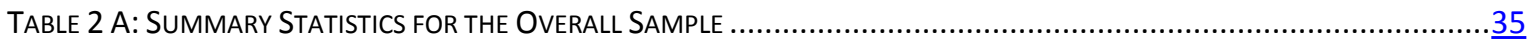

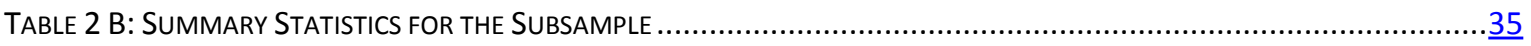

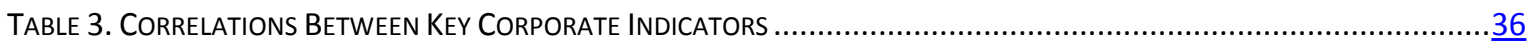

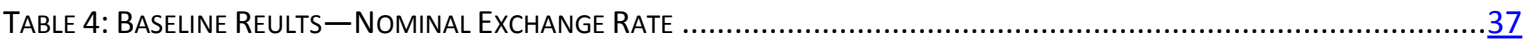

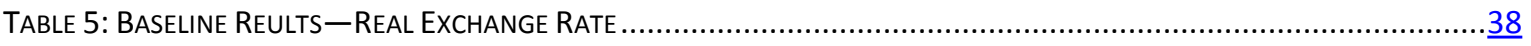

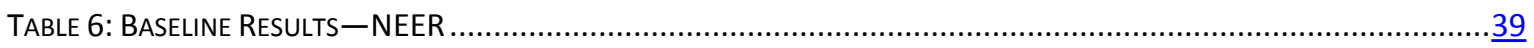

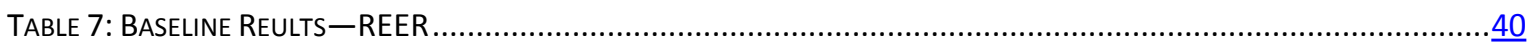

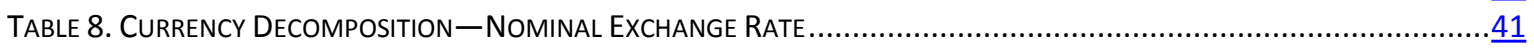

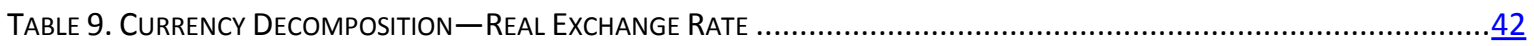

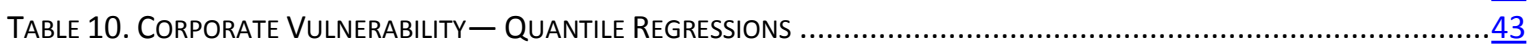

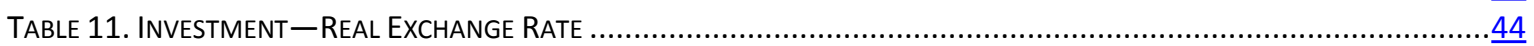

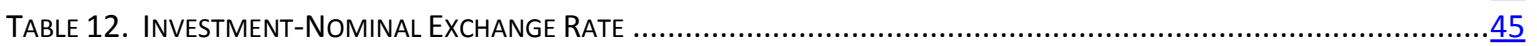

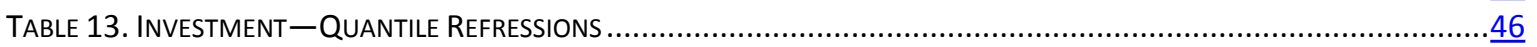

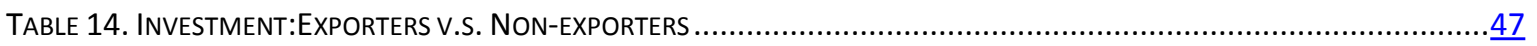




\section{INTRODUCTION}

Global corporate debt has more than doubled over the past decade. A large share of the growth in corporate debt has come from Asian countries, leading to high corporate debt levels across most of the region. While corporate debt has been rising across the region, most notably in emerging Asia, the buildup of leverage - notably the US dollar debt - accelerated following the global financial crisis. ${ }^{2}$ Corporate debt levels in Asia are generally higher than in other regions (Figure 1).

This high leverage is due to both rapid credit growth and significant corporate bond issuance. Accommodative U.S. monetary conditions contributed to the surge in corporate leverage (IMF, 2015; and Alter and Elekdag, 2016). More broadly, the fall in global interest rate and the rise of dollar-denominated international bond issuance, the so-called "second phase of global liquidity" contributed to the sharp increase in corporate debt (Shin, 2013). ${ }^{3}$

While greater corporate leverage can be used for financing investment, thereby boosting productivity and growth, the sharp upward trend in recent years raises concerns about financial stability. Tighter global financial conditions, previewed by the May 2013 "taper tantrum," and more recently in 2018, could exacerbate corporate debt service burdens. Indeed, rising global interest rates could trigger capital outflows, weaker local currencies, and lower earnings. The effect might come both from the quantity (a tighter supply of dollars) and the price (higher cost of borrowing). Such developments could increase corporate stress, especially among firms that have issued dollar-denominated debt, and potentially trigger broader financial stress and dampen economic activity (Powell, 2017; Shin, 2013; McCauley et al., 2015; Acharya et al., 2015). The turning tide raises some critical questions. How vulnerable are Asian corporates to tighter global financial conditions? And how has corporate vulnerability in the region evolved since the Asian financial crisis (AFC)?

Theoretically, if higher global interest rates reflect stronger external demand, this would benefit firms, especially exporters. However, higher global interest rates could trigger capital outflows (Figure 2), currency depreciation and tighter domestic financial conditions, which could interact with and exacerbate balance sheet weaknesses. The impact would be greater for firms with high foreign currency-denominated debt.

\footnotetext{
${ }^{2}$ In emerging Asia, corporate debt increased to about 114 percent of GDP in 2017:Q4 from 71 percent in 2007:Q4. While the total stock of US dollar-denominated debt of non-banks in emerging Asia increased to about USD 1.4 trillion in 2017:Q4 from USD 0.41 trillion in 2007:Q4.

${ }^{3}$ The first phase of global liquidity, during the period leading to global financial crisis, had global banking at its center, with looser financial conditions across borders transmitting through the acceleration of banking sector capital flows. The second phase of global liquidity started after the global financial crisis, with the bond market playing an important role. The transmission of financial conditions across borders took the form of "reaching for yield," the decline of risk premiums for debt securities and the explosion in issuance of international debt securities (Shin, 2013).
} 
An exchange rate depreciation can have two opposing effects on firms' financial condition and thus vulnerability. The first is a financial channel effect and works through the firms' balance sheet conditions: a currency depreciation makes the firms' debt burden heavier especially when the firm borrows heavily in foreign currencies. ${ }^{4}$ The second is a potential positive effect through the real output channel or trade channel. Namely, the depreciation makes the exporting goods cheaper and thus increases the firms' profitability, especially for export intensive firms and those that use local inputs. ${ }^{5}$ Therefore, given these opposing effects, the net impact of exchange rate movements on corporate vulnerability is ultimately an empirical question. Depending on the net effect, the exchange rate can act as a shock absorber or a shock amplifier.

Using a newly constructed firm-level dataset with comprehensive information on Asian firms' FX liabilities, we estimate the effect of the exchange rate on corporate vulnerability. In particular, we focus on the impact of the exchange rate on corporate vulnerabilities conditional on leverage in foreign currency. The firm-level empirical literature on corporate vulnerability with respect to the exchange rate is scarce and inconclusive, especially for emerging market economies (EMEs), ${ }^{6}$ on account of a paucity of data on the currency decomposition of corporate debt. ${ }^{7}$ We fill this gap by constructing a new firm-level database with comprehensive information on the FX liabilities of firms in 12 Asian economies over 1994-2016. This allows us to assess the impact of exchange rate on corporate vulnerability conditional on leverage in foreign currency at the firm level.

Our paper makes two main contributions to the literature. First, following Alfaro et al. (2017), we construct an aggregate measure of corporate vulnerability at the firm level (the Altman's Emerging Market Z' -score) for a large sample of Asian firms. The Altman Z-score is a summary measure of corporate vulnerability based on financial ratios of profitability, leverage, liquidity, and solvency. Lower Z-scores are associated with a higher probability of corporate bankruptcy. In other words, instead of assessing different ratios in isolation (single

\footnotetext{
${ }^{4}$ Another channel (the aggregate lending channel) operates in the same direction-weaker balance sheets of banks impairs their capacity to lend and reduces firms' access to finance. Dao et al. (2017) derive and test an "internal financing channel" through which variations in the real exchange rate affect corporate investment and firm growth through the availability of internal financial resources.

${ }^{5}$ However, the short-run response of trade flows to exchange rate movements can be asymmetric due to trade pricing in dominant currencies (Gopinath, 2015; Casas and others, 2016). Specifically, with dominant currency pricing, a depreciation against the dominant currency may reduce imports but has no impact on exports. Also, the relationship between exchange rate adjustment and trade flows may have been weakened by the build-up of global value chains (Amiti et al., 2012).

${ }^{6}$ The existing empirical literature of the impact of depreciations, associated with a deterioration of firms' balance sheets through increased liability/decreased collateral value when a substantial share of debt is denominated in foreign currency, is inconclusive. For example, Bleakley and Cowan (2008) and Aguiar (2005 estimate the effect of firm balance sheet channel, with mixed results.

${ }^{7}$ Some papers have recognized the issues of having data on the currency composition at the firm-level and have used an alternative approach — namely, compiling firm-level data at the country level and using the information about the currency composition.
} 
dimension), we combine them into an overall indicator (multiple dimensions). Methodologically, this multivariate approach has proven to be superior to univariate approaches in predicting corporate distress (Altman, 2016). Economically, using, for example, high corporate leverage alone as an indicator of corporate distress may be misleading, as it could indicate both the availability of profitable projects and high risk, and it misses other dimensions of corporate vulnerability. More importantly, Altman (2005) establishes a correspondence between the Z"'-score and corporate bond ratings in EMEs, so this aggregate measure could be interpreted as an indicator of firms' probability of default.

Second, we construct a new and comprehensive dataset of the currency decomposition of corporate debt. Previous works such as Serena and Sousa (2017) and Bruno and Shin (2017 and 2018) used only bond issuance denominated in U.S. dollar as a measure of U.S. dollar debt portion at corporate level. Though corporate bond issuance in U.S. dollar has increased rapidly in recent years, syndicated loans are still the dominant source of foreign currency debt issuance for not only larger firms but also for medium-and small-sized corporates. Excluding syndicated loans from firms' FX liability would miss an important factor of corporate vulnerability. Finally, including the period prior to the AFC provides a crucial benchmark for comparison. ${ }^{8}$

The main findings of our work are as follows:

- $\quad$ The Altman Z'-score shows that Asia's nonfinancial corporate sector is in general healthier than it was in the runup to the AFC, but corporate vulnerabilities are higher in some Asian economies, including Hong Kong SAR, Indonesia, the Philippines, and Singapore (Figures 3).

- We find that in general the exchange rate has acted as a shock amplifier-not a shock absorber - for the Asian corporate sector. Specifically, we find that the exchange rate depreciation increases the probability of default of Asian firms. We find both statistically and economically significant association between corporate's sector vulnerability in Asia and local currency depreciation against US dollar, both in nominal and real terms. A 30 percent domestic currency depreciation against the U.S. dollar is associated with a 0.4 decrease in the Z"-score, which corresponds, on average, to a two-notch downgrade in the corporate credit rating (e.g., from A to $\mathrm{BBB}+$ ). Such a shock will result in 7 percent of firms in our sample falling into Drating bucket (or falling into bankruptcy). These results remain robust when we replace the bilateral exchange rate by the NEER or REER, and after controlling for other factors such as the VIX.

\footnotetext{
${ }^{8}$ As highlighted by Alfaro et al. (2017), historically, emerging market crises arose from sovereign debt problems, and twin banking and currency crises (Reinhart and Rogoff, 2009). However, the underlying microeconomic roots attributed to the AFC include corporate debt vulnerabilities (Pomerleano,1998; Corsetti et al. 1999). The crisis was accompanied by widespread corporate failures due to adverse balance sheet effects via currency and maturity mismatches at the firm level. Thus, AFC is a natural benchmark to assess corporate sector vulnerabilities in Asia.
} 
- We also find that changes in U.S. monetary policy rates have significant effects on Asia's corporate vulnerability, with a tightening of U.S. monetary policy increasing corporate sector vulnerability in Asia.

- $\quad$ Focusing on a smaller sample with available data on FX liability, we find that the effect of the exchange rate on corporate vulnerability is conditional on the level of foreign currency debt. Using interaction regressions, we find that the marginal impact of local currency depreciation on corporate vulnerability is stronger when the share of U.S. dollar denominated debt on firms' balance sheet is higher. ${ }^{9}$ Using quantile regressions, we find that when the share of U.S. dollar debt is below 10 percent, the competitiveness channel dominates the financial channel; when the share of U.S. dollar debt is between 10 and 20 percent, the financial channel offsets the competitiveness channel; and when the share of U.S. dollar debt is higher than 20 percent, the financial channel dominates. These results suggest that high FX liability amplifies the effect of exchange rate on corporate vulnerability. That is, exchange rate fluctuations act as shock amplifier, not absorber.

- $\quad$ Finally, we find that an exchange rate depreciation increases firm-level investment on average, but the relationship reverses for firms with large FX liabilities, and investment contracts with depreciation. In line with the results for the corporate vulnerability, we find that the impact of currency depreciation on firm level investment is conditional on U.S. dollar debt. In other words, as the firms' FX liability increases, the financial channel of exchange rates offsets the trade channel or the competitiveness channel. Furthermore, this debt-overhang channel is shown to be more significant for non-exporter firms.

The remainder of the paper is organized as follows. Section 2 describes and discusses the motivation of using the Altman Z' -score as a measure of overall corporate vulnerability. Section 3 describes the data construction and the regression models that we use to conduct the analysis. Section 4 presents the empirical results. Section 5 concludes and provides some policy implications.

\footnotetext{
${ }^{9}$ While we use a new firm-level dataset with comprehensive information on Asian firms' FX liabilities, our results are consistent with those of Alfaro et al. (2017) and Serena and Sousa (2017). Alfaro et al. (2017) find that the interaction between the firms' overall leverage and depreciation of domestic currency against USD negatively impact the firms' Z' -score. They conjecture that FX loans explain their results: "While we do not have data on the currency composition of firm-level debt, the finding that currency movements amplify the correlation between leverage and corporate financial fragility would be consistent with the presence of currency mismatches." We show that FX loans indeed explain the results. Serena and Sousa (2017) find that the interaction between domestic currency depreciation and the amount of USD denominated bond on firms' balance sheet is negatively correlated with firms' investment. Our paper goes beyond the existing literature by providing a comprehensive measure of leverage in USD, including both bank loan and bond issuances. More generally, our paper documents the vulnerability brought by USD leverage and quantifies when the balance sheet channel of exchange rate offsets, then dominates, the competitiveness channel.
} 


\section{The Altman EME Z'-ScORE}

The Altman Z'"-score is a well-established indicator of corporate vulnerability in EMEs. The Z-score was first developed by Edward Altman in his 1968 paper on corporate bankruptcy prediction. He later refined the score and created a new version for EME firms using data from EME corporates (Altman, 2005), the so-called Z' '-score. He shows that this updated version predicts well the default probabilities for both manufacturing and non-manufacturing firms in EMEs, and for both private or listed firms. Importantly, Altman (2005) establishes a correspondence between the Z' -score and corporate bond ratings in EMEs, so this aggregate measure could be interpreted as an indicator of probability of default of firms (Text Table 1). Altman et. al (2016) further reassessed the Z' '-score using a wider sample of emerging market corporate data. The authors show that the Z' '-score predicts well the default risk against other alternative model specifications.

The Altman (2005) Z"'-score for EME firms is defined as follows: ${ }^{10}$

$$
\begin{aligned}
& Z^{\prime \prime}=3.25+6.56\left(X_{1}\right)+3.26\left(X_{2}\right)+6.72\left(X_{3}\right)+1.05\left(X_{4}\right) \\
& \text { Where } X_{1}=\frac{\text { working capital }}{\text { total assets }} ; X_{2}=\frac{\text { retained earnings }}{\text { total assets }} ; \\
& \qquad X_{3}=\frac{\text { operating income }}{\text { total assets }} ; \text { and } X_{4}=\frac{\text { total equity }}{\text { total liabilities }}
\end{aligned}
$$

The first variable $\left(X_{1}\right)$ is a measure of liquidity since working capital is defined as the difference between current assets and current liabilities. According to Altman (1968, 2005, and 2016), this ratio statistically dominates current ratio and quick ratio in predicting default probabilities. The variable $X_{2}$ is a measure of leverage, based on the pecking order theory popularized by Myers and Majluf (1984). This theory stipulates that corporates adhere to a hierarchy of financing sources and prefer internal financing when available, and debt is preferred over equity if external financing is required. The variable $X_{3}$ is a measure of profitability. The operating income is simply the commonly used earnings before interest and taxes (EBIT). This variable measures the earning power of corporates assets, independent of any tax or leverage factors. Finally, the ratio $X_{4}$ measures the corporate's solvency. It measures how much the corporate's asset value can drop before it finally become insolvent.

\section{Text Table 1: Altman Z''-score and Corporate Bond Ratings Correspondence}

\footnotetext{
${ }^{10}$ As explained in Altman (2005), the constant term is derived from the median Z''-score for bankrupt U.S. firms. The intention was to make the firms who has default-equivalent rating (D) in bond market to receive a Z' '-score equal to zero. To implement this, U.S. bankrupt (or D-rated) firms' balance sheet ratios were plugged into the Z' '-score formula without constant terms, and the median Z' of this subset of firms was -3.25 , so that the overall Z', score formulation was shifted up by 3.25 to standardize the gap. After re-plugging the bankrupt EME sub-sample into the full Z"'-score formula with the 3.25 as constant, the median of this EME sub-sample bankrupted firms is found to be 1.75 , though not exactly zero, but close. The constant term is only for standardization and does not affect the distribution of the Z' ' in EMEs.
} 


\begin{tabular}{|c|c|c|c|c|c|}
\hline & Z-score & Rating & Z'score & Rating & \\
\hline \multirow{11}{*}{ Safe Zone } & $>8.5$ & AAA & $5.65-5.85$ & BBB- & \multirow{7}{*}{ Grey Zone } \\
\hline & $7.60-8.15$ & $\mathrm{AA}+$ & $5.25-5.65$ & $\mathrm{BB}+$ & \\
\hline & $7.30-7.60$ & AA & $4.95-5.25$ & BB & \\
\hline & $7.00-7.30$ & AA- & $4.75-4.95$ & BB- & \\
\hline & $6.85-7.00$ & $A+$ & $4.50-4.75$ & $B+$ & \\
\hline & $6.65-6.85$ & A & $4.15-4.50$ & B & \\
\hline & $6.40-6.65$ & A- & $3.75-4.15$ & B- & \\
\hline & $6.25-6.40$ & $\mathrm{BBB}+$ & & & \multirow{4}{*}{ Distress Zone } \\
\hline & $5.85-6.25$ & BBB & $3.20-3.75$ & $\mathrm{CCC}+$ & \\
\hline & & & $2.50-3.20$ & $\mathrm{CCC}$ & \\
\hline & & & $\begin{array}{r}1.75-2.50 \\
<1.75\end{array}$ & $\begin{array}{c}\text { CCC- } \\
D\end{array}$ & \\
\hline
\end{tabular}

Source: Altman (2005).

The Altman Z''-score is a better measure of the corporate vulnerability than any single indicator. There are two reasons why the Altman Z' -score is superior to using a single measure such as leverage ratio, interest coverage ratio (ICR) ${ }^{11}$ or Debt-at-Risk:

- $\quad$ Statistically, the Z' '-score dominates single ratios in predicting default probability. More importantly, Altman et al. (2016) show that the score works well under alternative model specifications such as logit or probit models, and the coefficients are not obsolete.

- From an economic perspective, an increase in corporate leverage, for example, could be driven by risky firms' refinancing or other risky decision such as gambling for resurrection from firms with weak fundamentals, by higher investment demand due to availability of profitable projects and under-developed equity market, or by younger firms' entry into the market. Therefore, an increase in leverage alone should not always be interpreted as higher corporate distress.

Figures 3 and 4 present the Z' '-score and the ICR for the 12 economies for 1996 and 2016. For each economy in our sample, the evolution of the Z' '-score over 1994-2016 as well as that of $X_{1}, X_{2}, X_{3}$, and $X_{4}$ are presented in Figures 5-9.

\section{Data And Methodology}

\section{A. Data}

An important contribution of this paper is the construction of currency decomposition of Asian corporates' debt at the firm level. Decomposing currency denominated debt is important because without concrete information on how much firms have issued debt in foreign currencies - U.S. dollar is the main currency denomination choice of foreign debt-

\footnotetext{
${ }^{11}$ ICR is calculated as operating income (EBIT) divided by total interest expenses on debt. ICR is used to determine how easily a company can pay interest on its outstanding debt.
} 
one cannot identify the impact of the competitiveness (export profits) and the balance sheet (the burden of FX debt) channels, which have opposite effects.

Our data come from two main sources: Thomson Reuters Datastream Worldscope and Thomson One Banker. Our data on firms' balance sheet information come from Thomson Reuters' Datastream Worldscope. This database provides detailed historical information for the listed firms of a wide sample of countries. Worldscope is best suited for the aim of our paper for two reasons. First, country, year and firm coverage is more comprehensive in Worldscope than other major databases such as ORBIS. The aim of the paper is to study the corporate vulnerabilities of emerging countries in Asia since the AFC, our benchmark for corporate distress in Asia. Worldscope is the only database, to the best of our knowledge, that offers relatively complete firm observations, covering most countries with the longest horizon. Second, we use Thomson One Banker to decompose the leverage by currencies at the firm level. ${ }^{12}$ Worldscope and Thomson One Banker share the same underlying firm identifiers, facilitating the merger of the two databases at the firm level.

Our sample covers balance sheet information of 12 major economies in Asia. These are China, Hong Kong SAR, India, Indonesia, Korea, Malaysia, Philippines, Singapore, Sri Lanka, Taiwan POC, Thailand and Vietnam. The year of data coverage ranges from 1994 to 2016, but for Vietnam, the availability of data starts from 2005. To better compare the preAsian financial crisis' non-financial corporate sector performance, we include both active firms and inactive firms in our sample ${ }^{13}$. We exclude observations with noticeable error as well as those that are outliers. We first exclude observations with no total asset data. We don't want the outliers to distort the regression results. Therefore, we winsorize the data by dropping outliers whose Z' '-score, return to asset (ROA) or leverage is outside the range of 0.5-99.5 percentile of the whole sample. The resulting sample is an unbalanced panel dataset including 200681 firm-year observations, which includes about 18000 firms. The summary statistics of firms' balance sheet information is provided in Tables 2 and 3.

To decompose the foreign currency debt issuance, we construct our sample by using not only the information on bond issuance but also on the syndicated loan issuance. This is important given that syndicated loans are still the main source of external financing for corporates in EMEs. Also, as shown by Ivashina and Becker (2014), bank loans are more volatile and cyclical than bond issuance, indicating that syndicated loans issuance could amplify corporate vulnerability. Importantly, majority of the cross-border syndicated loans are denominated in U.S. dollar. Figures 10 and 11 show the volume of syndicated loan issuance according to our data in U.S. dollar and domestic currencies in Asia over the past 20 years, as

\footnotetext{
${ }^{12}$ Constructing firms' USD debt level using issuance data has advantage over the reported balance sheet data. First, not all countries require firms (especially Asian firms) to report the proportion of USD debt on the balance sheet. That is, this is not a compulsory balance-sheet item, but rather a discretionary note. Second, using balance sheet items might suffer from mismeasurement issues resulting from firms' lack of incentive to disclose the information accurately. Thus, foreign currency debt from financial statements is neither comprehensive nor necessarily consistent across firms.

${ }^{13}$ Firms become inactive either because they went bankrupt or because they become delisted for some other reasons.
} 
well as the comparison with bond issuance in both domestic currencies and U.S. dollar. Our micro data also show the average maturity of foreign currency debt has decreased, while that of local currency debt has increased (Figures 12 and 13).

\section{B. Empirical Methodology}

Using the Z"'-scores as a measure of overall corporate vulnerability, our general regression specification could be summarized as follows:

$$
Z_{i, j, t}=\alpha+\beta_{1} F_{i, j, t}+\beta_{2} M_{j, t}+\beta_{3} S_{i, j, t} \times E R_{j, t}+\beta_{4} S_{i, j, t} \times I R_{t}+\mu_{i}+\varepsilon_{i, j, t}
$$

Where $Z_{i, j, t}$ is the (firm level) Altman Z'-score of company $\mathrm{i}$, in country $\mathrm{j}$, at time $\mathrm{t}, \alpha$ is the constant, $F_{i, j, t}$ is a vector of firm-level variables, $M_{j, t}$ is a vector of macro or market level variables for country $\mathrm{j}, E R_{j, t}$ is change in exchange rate, $I R_{t}$ is a measure of global interest rates (or domestic short-term interest rate), $S_{i, j, t}$ represents the share of U.S. dollar denominated debt on firm i's balance sheet at year $t$, and $\mu_{i}$ is the company specific fixed effect. ${ }^{14}$

To assess the impact of exchange rate on firm-level investment, we use the following specification:

$$
\Delta Y_{i, j, t}=\alpha+\beta_{1} F_{i, j, t}+\beta_{2} M_{j, t}+\beta_{3} S_{i, j, t} \times E R_{j, t}+\mu_{i}+\varepsilon_{i, j, t}
$$

$\Delta Y_{i j, t}$ represents the percentage changes in capital expenditures, a proxy for firm's investment. The other variables' definitions are the same as in equation 1, with $S_{i, j, t}$ representing the share of U.S. dollar denominated debt on firm i's balance sheet at year t. We also run these regressions comparing firms that are exporters and non-exporters.

\section{EMPIRICAL RESUlts}

In this section, we present our empirical findings using the firm-level data. The baseline results show how global financial conditions affect corporate vulnerability. These results are driven from a large sample of Asian firms. Then focusing on a smaller sample and using FX liability at the firm level, we show how exchange rate movements affect corporate vulnerability and investment, conditional on foreign currency liability. We also show whether these results are different for exporters and non-exporters.

\footnotetext{
${ }^{14}$ We provide regression tables with only firms' fixed effects here since year fixed effects and country-year fixed effects are captured by coefficients on VIX and a country's change in exchange rate. Regression results with all possible combinations of fixed effects remain qualitatively similar.
} 


\section{A. Baseline Results}

Table 4 shows the impact of bilateral nominal exchange rate against US dollar on corporate vulnerability. We find that a local currency depreciation is significantly associated with an increase in corporate vulnerability, as measured by the Z' '-score. ${ }^{15}$ This result is also economically meaningful. A 30 percent domestic currency depreciation against the U.S. dollar is associated with a 0.4 decrease in the $Z$ ' '-score, which corresponds, on average, to a two-notch downgrade in the corporate credit rating (e.g., from A to $\mathrm{BBB}+$ ). Such a shock will result in 7 percent of firms in our sample falling into D-rating bucket (or falling into bankruptcy), see Text Table 1. This association remains robust when we control for the U.S. shadow rate and when we control for risk appetite measured by VIX.

These results are intuitive in the context of EMEs. Weak dollar phases are associated with buoyant financial conditions, real economic activity and capital inflows to EMEs (Avdjiev et al. 2018). In contrast, strong dollar phases are associated with tighter financial conditions, slowing real economic activity and capital outflows from EMEs. The credit constraint channel is another explanation. As discussed by Hofmann et al. (2017), depreciation of local currency against the U.S. dollar increases the credit risk premium. This tends to tighten firms' credit constraints and thus decrease firms' profitability. For firms with a large proportion of their debt denominated in US dollar, the depreciation of local currency against U.S. dollar will affect individual firms' status through the balance sheet channel.

Depreciation will exacerbate firms' financial burden if the firms have a considerable amount of debt denominated in US dollar.

Our baseline results in Table 4 also show that the changes in domestic short-term interest rate are negative but insignificantly associated with corporate vulnerability. By contrast, changes in U.S. shadow rate do show a strong negative association with the corporate vulnerability. The association is robust after controlling for changes in VIX and bilateral exchange rate. These results suggest that US interest rates matter more for corporate vulnerability than domestic interest rates.

There are two main mechanisms through which increases in U.S. policy rates negatively affect corporate balance sheet conditions. First, increases in U.S. rates imply tighter supply of U.S dollars. Not only do firms that need external financing face higher interest rates, but also global banks who rely on whole-sale funding market face higher funding cost and thus decrease their supply of credit. Facing higher cost of financing, firms with external financing demand might have to cease or postpone their profitable projects, which may lead to lower Z' '-score. Second, higher U.S. policy rate goes hand in hand with U.S. dollar appreciation against local currencies. For firms with large amount of U.S. dollar on their balance sheets, appreciation of U.S. dollar makes their real debt burden heavier thus facing higher roll-over or default risk. This also leads to lower Z' '-score.

Table 5 shows the same set of baseline results for real bilateral exchange rate instead of the nominal exchange rate. The results are consistent with those in Table 4, with a slightly

\footnotetext{
${ }^{15}$ A positive change in exchange rate means an appreciation.
} 
smaller magnitude of the association between real exchange rate and corporate vulnerabilities. In Table 6 and Table 7, we provide the same set of exercises as in Table 4 and Table 5 but using the nominal effective exchange rate (NEER) and the real effective exchange rate (REER), respectively. Again, the association between corporate vulnerabilities and both the exchange rate measures are significant. But the magnitude is smaller compared to the results of bilateral exchange rate measures, likely driven by the fact that NEER and REER are less volatile. These results are consistent with those in Table 4 and Table 5, suggesting that an exchange rate depreciation indicates higher corporate vulnerability in Asia.

\section{B. Corporate Vulnerability: Competitiveness vs. Financial Channels of the Exchange Rate}

The trade channel and the financial channel of the exchange rate have opposite effects on corporate sector. The financial channel suggests that an exchange rate appreciation will stimulate domestic economic activity, while the trade channel can have the opposite effect. The strength of the financial channel depends on the sensitivity of the corporate balance sheets to the exchange rate and the amount of FX debt.

To capture these two effects of exchange rate on corporate vulnerabilities, we focus on the subsample of firms who ever had access to U.S. dollar denominated debt. Zooming into this subset of firms is important. While our database has the most extensive coverage of FX liability at the firm level, it is not exhaustive. In other words, some firms may have borrowed in FX but are not covered in our database. Therefore, using the full sample, we would implicitly assume that only firms in our database have borrowed in FX, which could distort the results.

In Table 8 and Table 9, using interaction models, we show that the effect of exchange rate on corporate vulnerability is conditional on foreign currency liability. In the first columns of Table 8 and Table 9, we find that local currency depreciation is significantly associated with corporate vulnerability, controlling for the proportion of U.S. dollar denominated debt on balance sheets. Moving forward to columns 4-6, we see that the marginal impact is stronger the higher the proportion of U.S. dollar denominated debt on firms' balance sheet, as the coefficient of the interaction variable is statistically significant. For a given firm, the higher the share of FX liability, the higher the impact of exchange rate.

In Table 10, using quantile regressions, we find that when the share of U.S. dollar debt is below 10 percent, the competitiveness channel dominates the financial channel (columns 13); when the share of U.S. dollar debt is between 10 percent and 20 percent (column 4), the financial channel offsets the competitiveness channel; and when the share of U.S. dollar debt is higher than 20 percent, the financial channel dominates (Column 6). These results suggest that high FX liability amplifies the effect of exchange rate on corporate vulnerability. That is, exchange rate fluctuations act as shock amplifier, not absorber. 


\section{Corporate Investment: Competitiveness vs. Financial Channels of the Exchange Rate}

We further analyze how exchange rate effects real activity by conducting an analysis on firms' investment behavior. We still focus on the subsample of firms that had access to U.S. dollar denominated debt, since this allows us to better identify and gauge the balance sheet effects. As discussed before, there are two main channels that the corporate vulnerabilities will be affected by the exchange rate. The first is the trade or the competitiveness channel. A depreciation in local currencies will enable exporters to expand their sales, thus increasing their profit and investment. The second is the financial channel. For firms that have U.S. dollar denominated debt, a depreciation in local currencies will make the real debt burden heavier and thus make the firm more vulnerable to default risk, contracting investment.

Table 11 and Table 12 show the results of interaction models. We are particularly interested in the coefficient on the interaction term between U.S. dollar denominated proportion of debt and local currency depreciation. We find that local currency depreciation against U.S. dollar is significantly associated with firms' investment expansion. The positive impact of the exchange rate depreciation on investment captures the real-side competition effect. But the real-side effect is offset by the balance sheet effect through exacerbating FX debt-overhang or the financial channel. As the firms' proportion of debt denominated in US dollar increases, the positive impact of the exchange rate depreciation declines, and at some point, it becomes negative. In other words, as the proportion of debt denominated in US dollar increases, the balance sheet channel dominates since the depreciation of local currency makes the real debt burden heavier, reducing firms' investment.

In Table 13, using quantile regressions, we find that when the share of U.S. dollar debt is below 10 percent, the competitiveness channel dominates the financial channel (columns 13); when the share of U.S. dollar debt is between 10 percent and 20 percent (column 4), the financial channel offsets the competitiveness channel; and when the share of U.S. dollar debt is higher than 20 percent, the financial channel dominates (Column 6). In line with the results for corporate vulnerability, these results suggest that high FX liability amplifies the effect of exchange rate on corporate vulnerability. That is, exchange rate fluctuations act as shock amplifier, not absorber.

In Table 14, we compare the above results between exporters and non-exporters. In the first two columns, we see the impact of local currency appreciation is negative for both exporters and non-exporters, but more significantly negative for exporters. Appreciation in local currency will make exporters' goods relatively less competitive compared with imported goods in the domestic market, thus lowering their profit and dampening their investment incentive. The figure 14 shows that the results are not driven by the differences in the two samples since the distribution of the exporters and non-exporters is broadly similar.

However, the marginal effect of exchange rate appreciation conditional on U.S. dollar denominated debt is more significantly negative for non-exporters. In other words, nonexporters that have borrowed in U.S. dollar are more sensitive to exchange rate fluctuations. The intuition is that the marginal impact of debt-overhang should be more significant when firms don't have natural hedging on currency, which means the firms being non-exporters. 
${ }^{16}$ The results hold when we use nominal exchange rate instead of real exchange rate. These results suggest that non-exporters with U.S. dollar debt on balance sheet, which means that they are more exposed to changes in international financing condition, will show more volatility in their investment than exporters with natural hedging through U.S. dollar revenue.

\section{CONCLUSION}

In this paper we construct a new firm level database for 12 Asian economies over 1994-2016, assess the corporate vulnerability, and identify the channels through which global financial conditions affect the corporate sector. According to the Altman Z' -score for EMEs, although nonfinancial corporate sector is healthier than it was in the runup to the Asian financial crisis, corporate vulnerability is higher in some Asian economies, including Hong Kong SAR, Indonesia, the Philippines, and Singapore.

We also find that Asia's nonfinancial corporates remain vulnerable to a tightening of global financial conditions. Specifically, regression analysis suggests that the probability of financial distress (that is, the inverse of the Z' '-score) increases with a tightening of US monetary policy. Similarly, local currency depreciation vis-à-vis the US dollar increases the probability of corporate financial distress. But the effect of exchange rate on corporate vulnerability is conditional on foreign currency liability. We find that when the share of U.S. dollar debt is below 10 percent, the competitiveness channel dominates the financial channel; when the share of U.S. dollar debt is between 10 and 20 percent, the financial channel offsets the competitiveness channel; and when the share of U.S. dollar debt is higher than 20 percent, the financial channel dominates.

Similarly, we find that an exchange rate depreciation increases firm-level investment on average, but the relationship reverses for firms with large FX liabilities, and investment contracts with depreciation. We also find that non-exporters that have borrowed in U.S. dollar are more sensitive to exchange rate fluctuations. Together with the findings for corporate vulnerability, these results suggest that high FX liability amplifies the effect of exchange rate on corporate sector. That is, exchange rate fluctuations act as shock amplifier, not absorber.

Against this background, Asian policymakers should monitor vulnerable firms, especially the systemically important, as well as banks and other sectors closely linked to them. Such efforts include filling data gaps on corporate sector finances, including foreign currency exposures and natural hedging. Macro and microprudential policies could help limit a further buildup of foreign exchange balance sheet exposures and contain excessive increases in leverage. With the shift in monetary policy in major advanced economies, Asian emerging markets should prepare for an increase in corporate failures and, where needed, reform corporate insolvency regimes.

\footnotetext{
16 The impact of exchange rate could also be mitigated if firms employ the use of derivatives to hedge against exchange rate volatility. However, such data are not available.
} 


\section{REFERENCES}

Acharya Viral, Stephen G. Cecchetti, José De Gregorio, Şebnem Kalemli-Özcan, Philip R. Lane, and Ugo Panizza, 2015. "Corporate Debt in Emerging Economies: A Threat to Financial Stability?”, Committee for International Policy Reform, Brookings Institution, Washington DC.

Acharya, Viral, Eisert, Tim, Eufinger Christian and Hirsch, Christian (2015), "Real Effects of the Sovereign Debt Crisis in Europe: Evidence from Syndicated Loans", Working Paper.

Aguiar, M., 2005, "Investment, devaluation, and foreign currency exposure: The case of Mexico," Journal of Development Economics, Vol. 78(1), pp.95-113.

Alfaro, Laura, Gonzalo Asis, Anusha Chari, and Ugo Panizza (2017), "Lessons Unlearned? Corporate Debt in Emerging Markets” NBER Working Paper No. 23407.

Alter, Adrian, and Elekdag, Selim (2016) "Emerging Market Corporate Leverage and Global Financial Conditions", IMF Working Paper.

Altman, Edward (1968), "Financial Ratios, Discriminant Analysis and the Prediction of Corporate Bankruptcy", Journal of Finance, Sep. 1968.

Altman, Edward (2005), “An Emerging Market Credit Scoring System for Corporate Bonds,” Emerging Market Review 6: 3011-323.

Altman, Edward, Iwanicz - Drozdowska, Małgorzata, Laitinen, Erkki and Suvas, Arto (2016), "Financial Distress Prediction in an International Context: A Review and Empirical Analysis of Altman's Z - Score Model”. Journal of International Financial Accounting and Management, Volume 28, Issue 2, June 2017, Pages 131-171.

Amiti, M, O Itskhoki, and J Konings (2012), "Importers, Exporter, and Exchange Rate Disconnect," CEPR Discussion Paper No. 9260.

Avdjiev, Stefan, Bruno, Valentina, Koch, Catherine, and Hyun Song Shin (2018), "The Dollar Exchange Rate as a Global Risk Factor: Evidence from Investment", BIS Working Papers, No 695.

Bleakly, Hoyt and Cowan, Kevin (2008) "Corporate Dollar Debt and Depreciation: Much ado about Nothing?” The Review of Economics and Statistics, MIT Press, vol. 90(4), pages 612-626, November.

Brauning, Falk and Victoria Ivashina (2017). Monetary Policy and Global Banking. NBER Working Paper No. 23316. Issued in April 2017. 
Bruno, Valentina and Hyun Song Shin (2015), "Capital Flows and the Risk-Taking Channel of Monetary Policy", Journal of Monetary Economics, Volume 71

Bruno, Valentina and Hyun Song Shin (2017), "Global Dollar Credit and Carry Trades: A Firm-level Analysis", Review of Financial Studies, vol 30, no 3, 2017, pp 703-49.

Bruno, Valentina and Hyun Song Shin (2018), "Currency depreciation and emerging market corporate distress”, BIS Working Papers | No 753.

Dao, Mai, Camelia Minoiu, and Jonathan D.Ostry, 2017, Corporate Investment and the Real Exchange Rate, IMF Working Paper WP/17/183.

Hofmann, Boris, Shim, Ilhyock and Shin, Hyun Song (2017), "Sovereign Yields and the Risk-Taking Channel of Currency Appreciation”, BIS Working Papers, No 538.

Ivashina, Victoria and Becker, Bo (2014), "Cyclicality of Credit Supply: Firm Level Evidence”, Journal of Monetary Economics, Volume 62, March 2014, Pages 76-93.

McCauley, Robert, Patrick McGuire and Vladyslav Sushko, 2015, Global dollar credit: links to US monetary policy and leverage, BIS Working Papers No 483.

Myers, Stwart and Majluf, Nicholas, 1984. "Corporate Financing and Investment Decisions when Firms Have Information that Investors Do Not Have.", Journal of Financial Economics, Volume 13, Issue 2, June 1984, Pages 187-221.

Powell, Jerome, 2017, Prospects for Emerging Market Economies in a Normalizing Global Economy, Speech, At the 2017 Annual Membership Meeting of the Institute of International Finance, Washington, D.C.

Serena, Jose Maria and Sousa, Ricardo, 2017. "Does exchange rate depreciation have contractionary effects on firm-level investment?", BIS Working Paper.

Shin, Hyun Song, 2013. "The second phase of global liquidity and its impact on emerging economies," Proceedings, Federal Reserve Bank of San Francisco, issue Nov, pages $1-10$.

Shin, Hyun Song and L Zhao (2013) "Firms as surrogate intermediaries: evidence from emerging economies", Working Paper, December 2013.

Wu, Jing, and Xia, Fan (2016), "Measuring the Macroeconomic Impact of Monetary Policy at the Zero Lower Bound", Journal of Money, Credit and Banking, Vol. 48, No. 2-3 


\section{APPENDIX I. FIGURES}

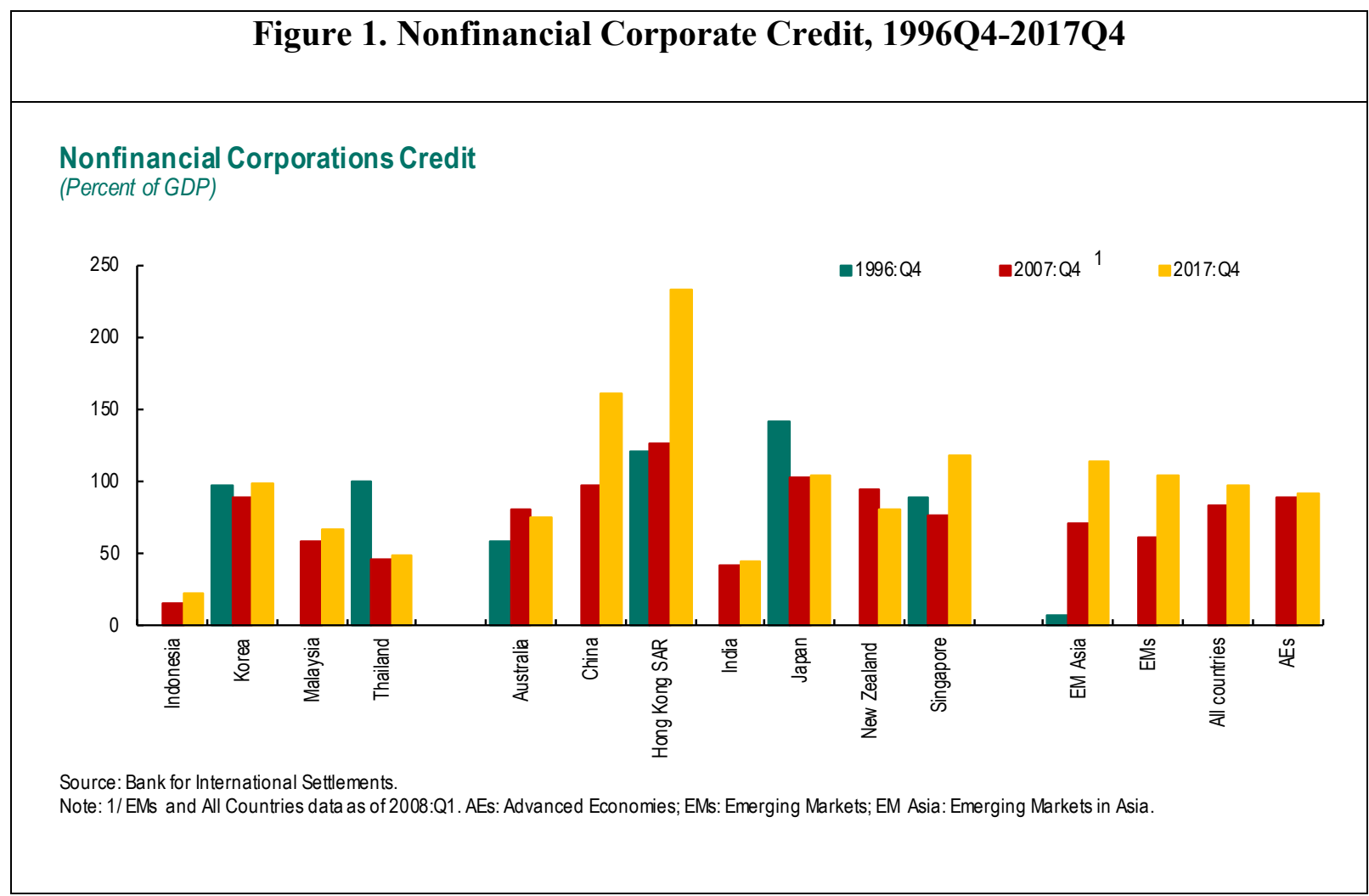




\section{Figure 2: U.S. Monetary Policy Conditions and Cross-border Bank Credit}

(A)

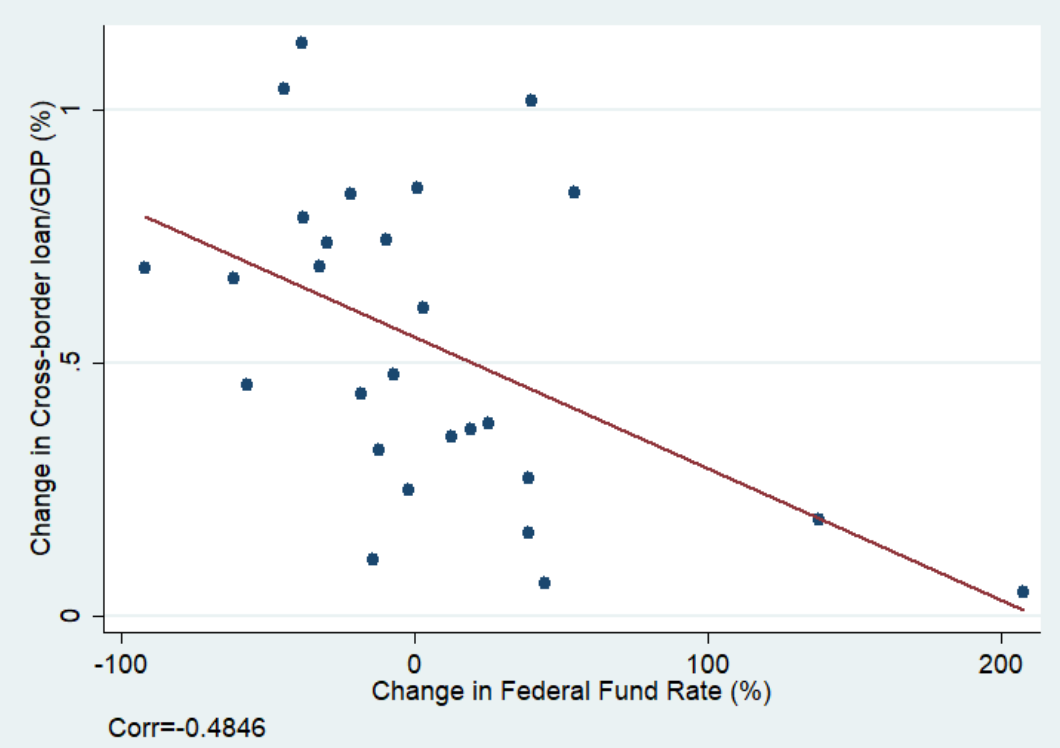

(B)

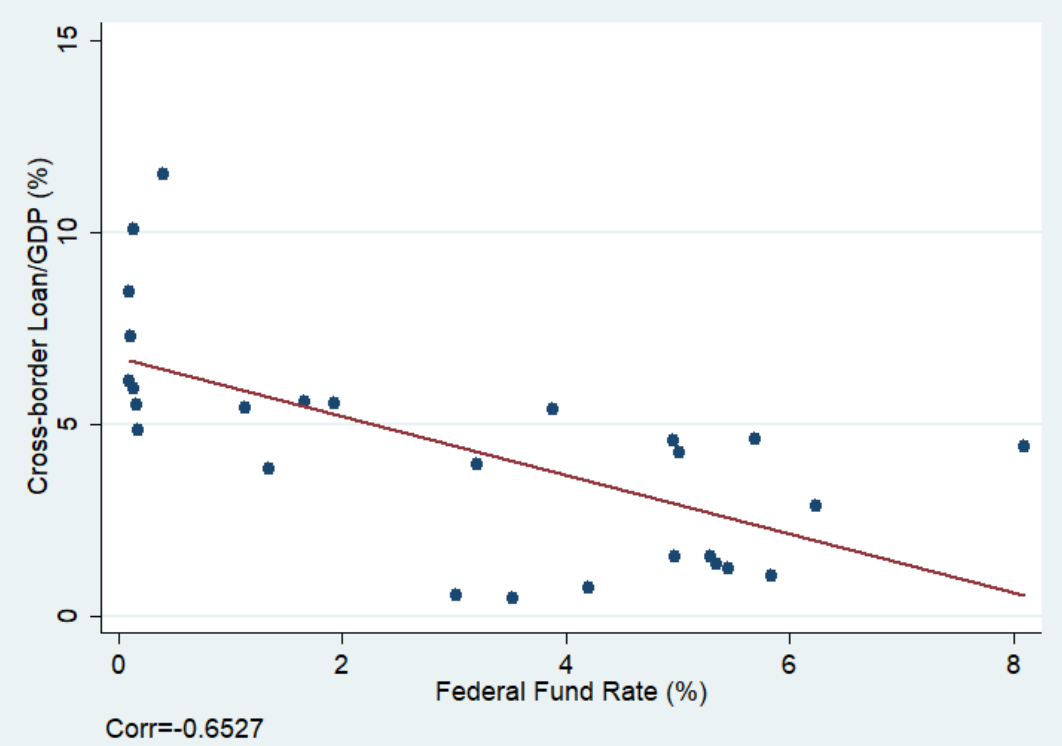

Source: Authors' caculation based on IMF's International Investment Positions. Cross-border lending is the "Debt Instruments" from foreign deposit-taking institutes. In panel (A), y-axis is the change in cross-border lending as a percentage of GDP lagged by one period, $\mathrm{x}$-axis is the percentage change of actual Fedral Fund Rate. In panel (B), y-axis is the total level of cross-border lending on the country's balance sheet divided by the GDP lagged by one period, $\mathrm{x}$-axis is the level of Federal Fund Rate. 

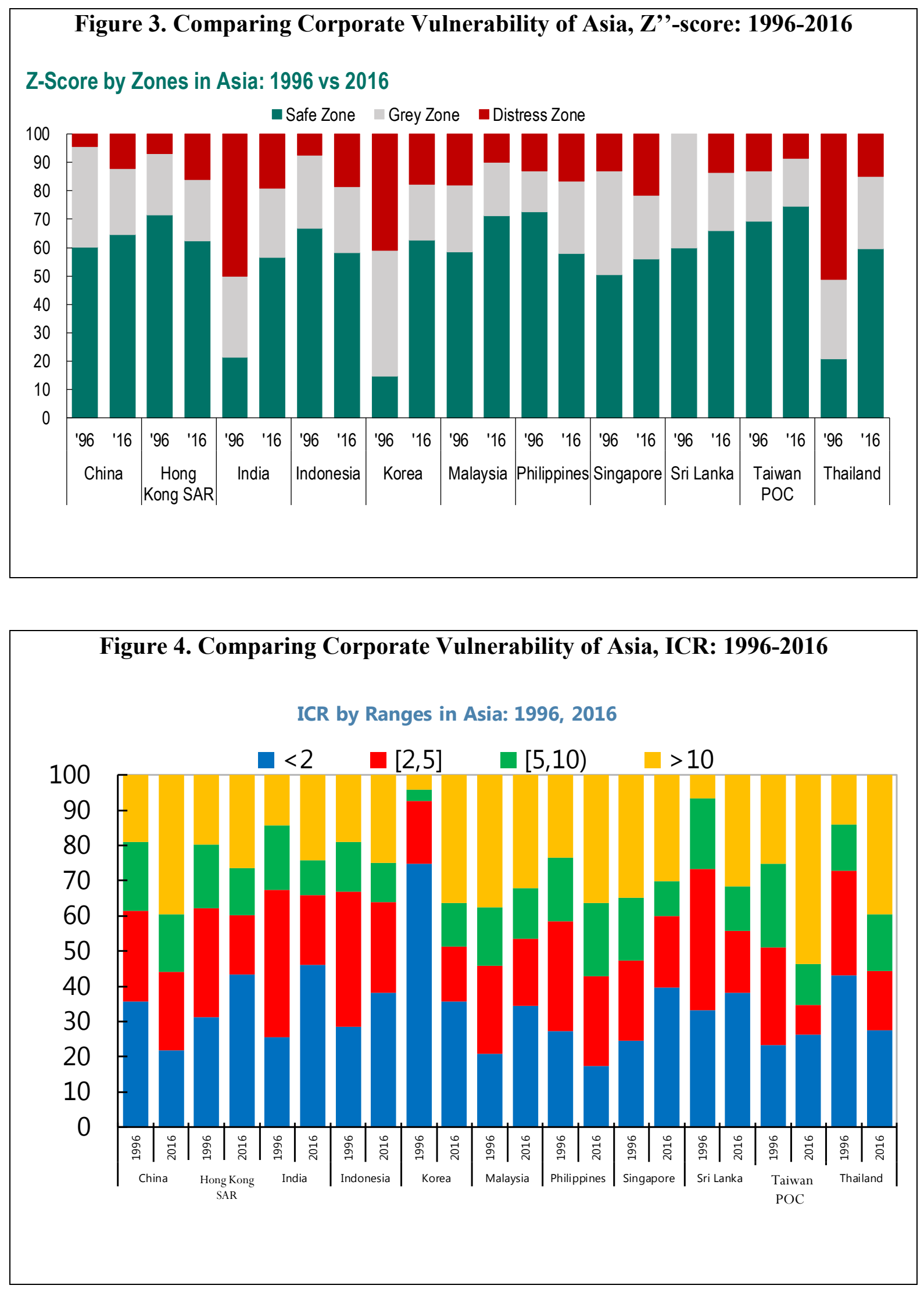


\section{Figure 5. Dynamics of Z''-score, 1994-2016}

The figures below plot the evolution of the Z' -score and its four components in 12 Asian economies over 1995-2015. The upper cap and the lower cap represents the level of the variable at 90th and 10th percentile in a given year, and the red dots represent the mean of the variable in a given year.
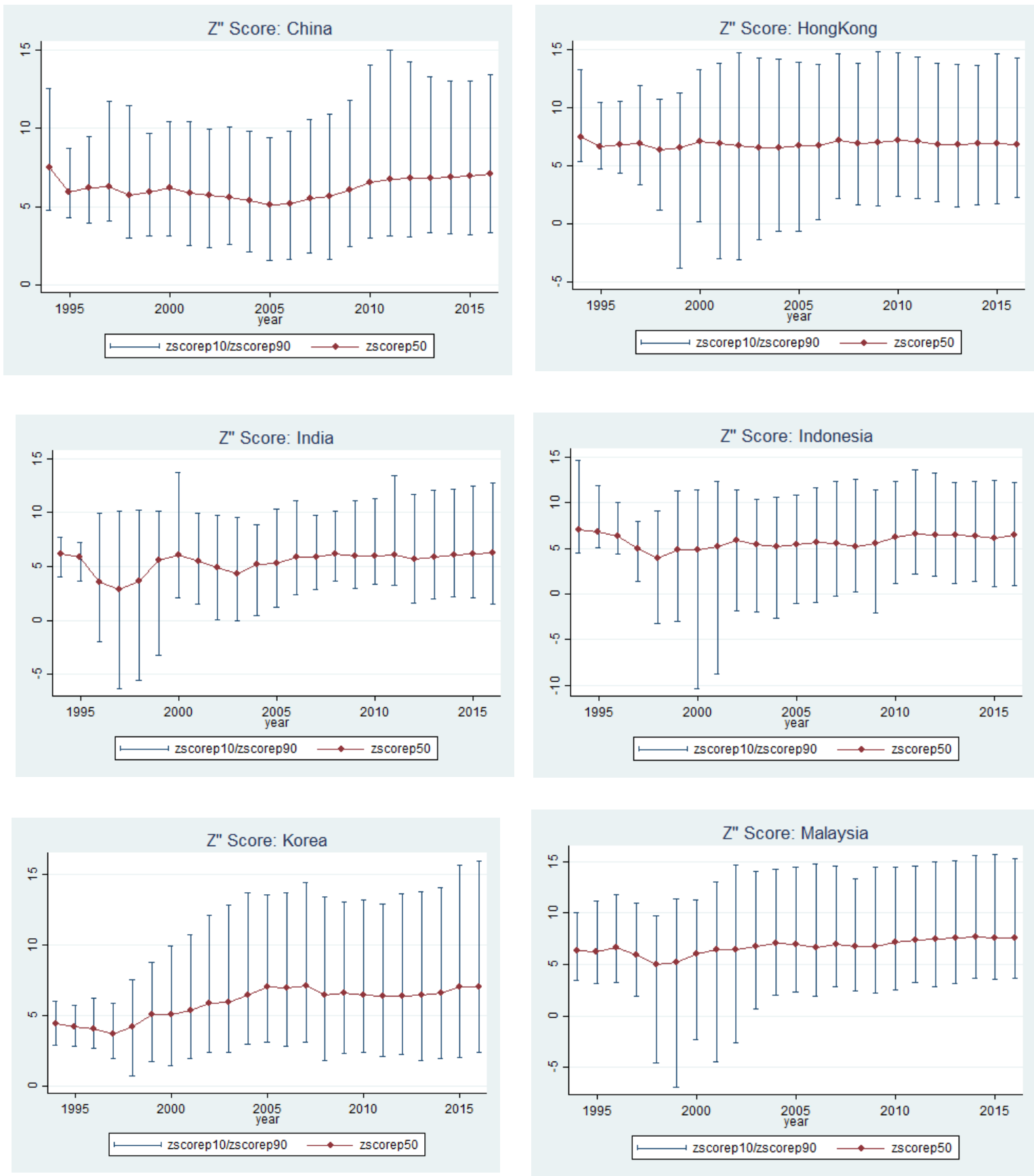


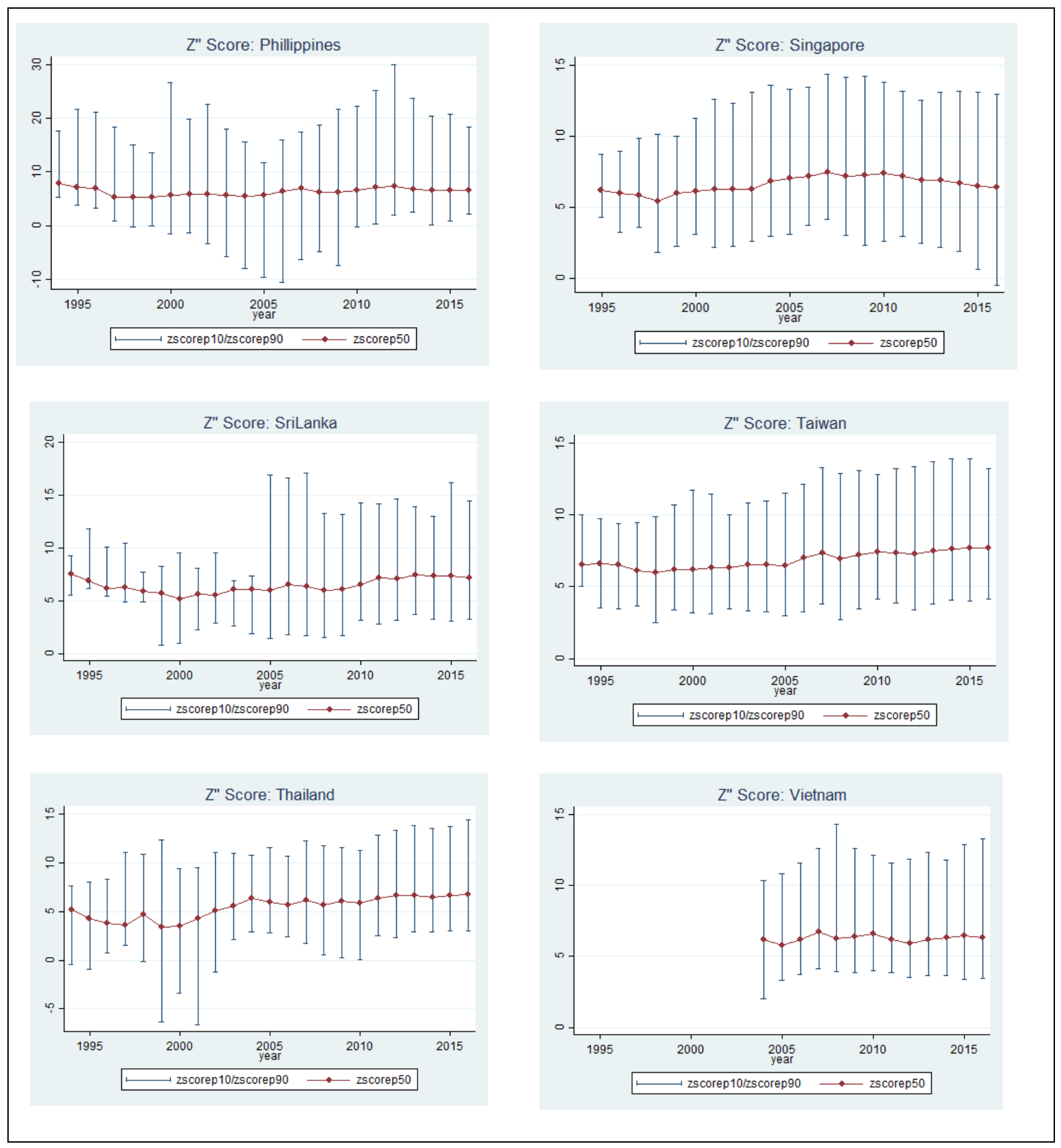




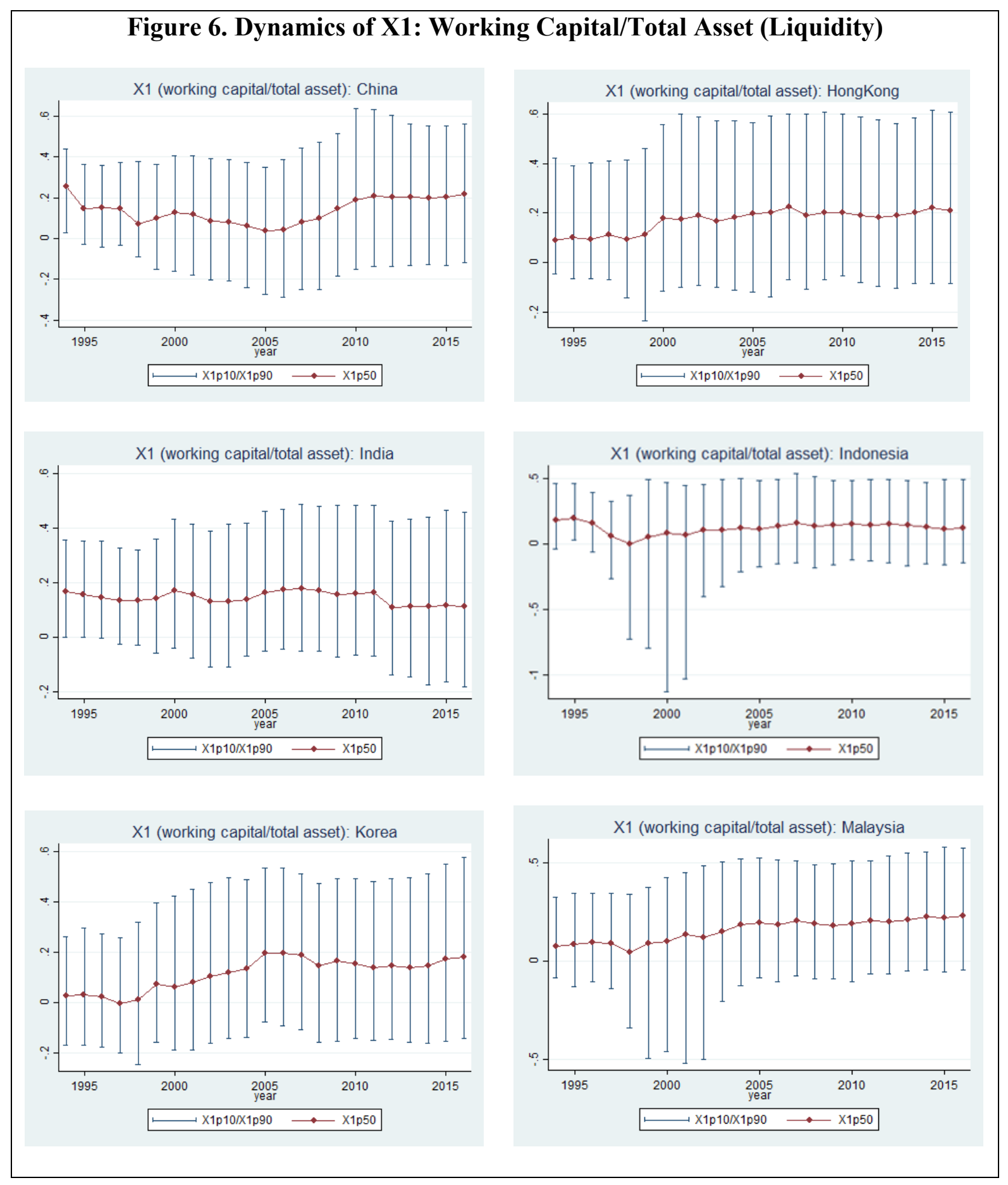




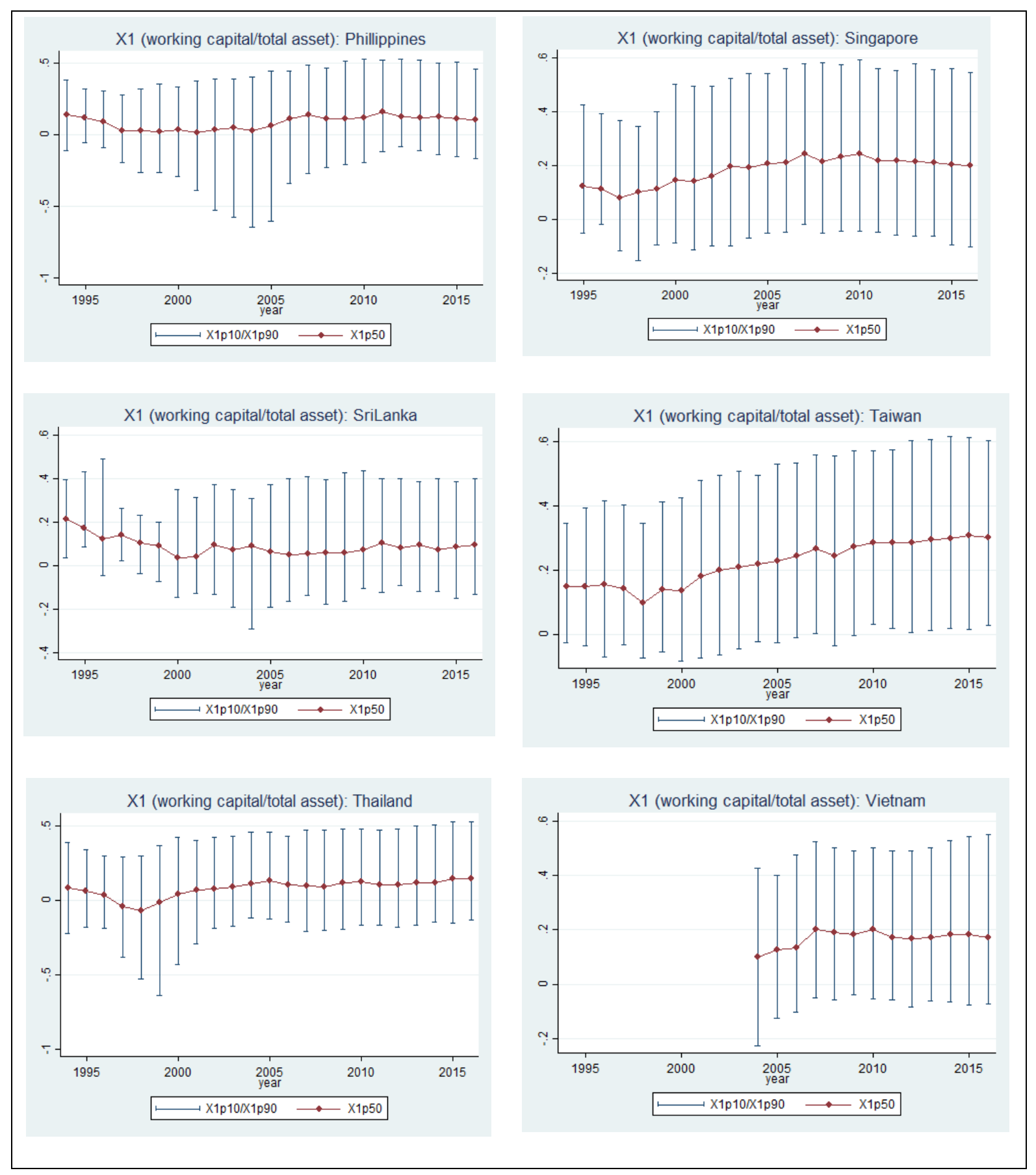




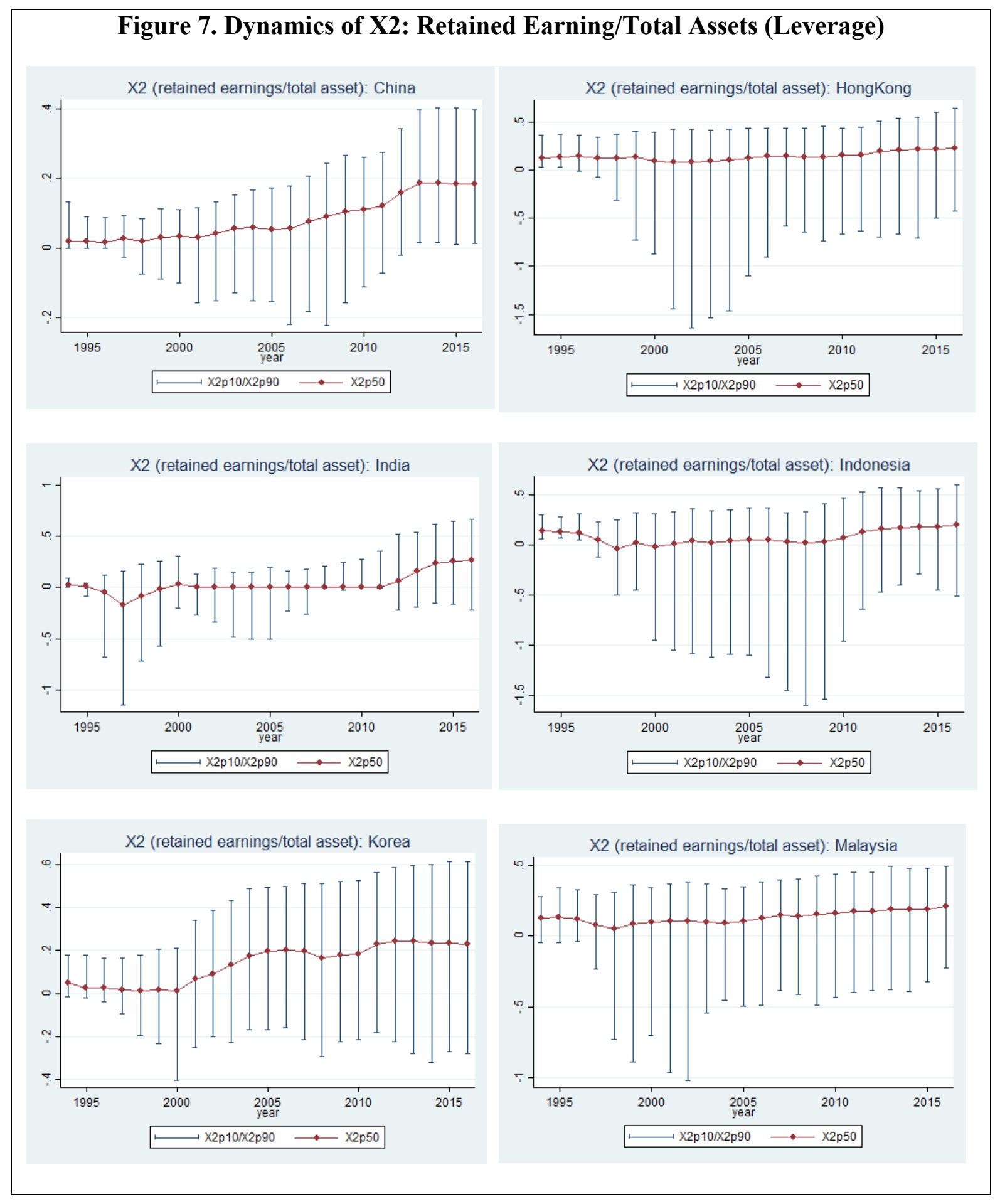




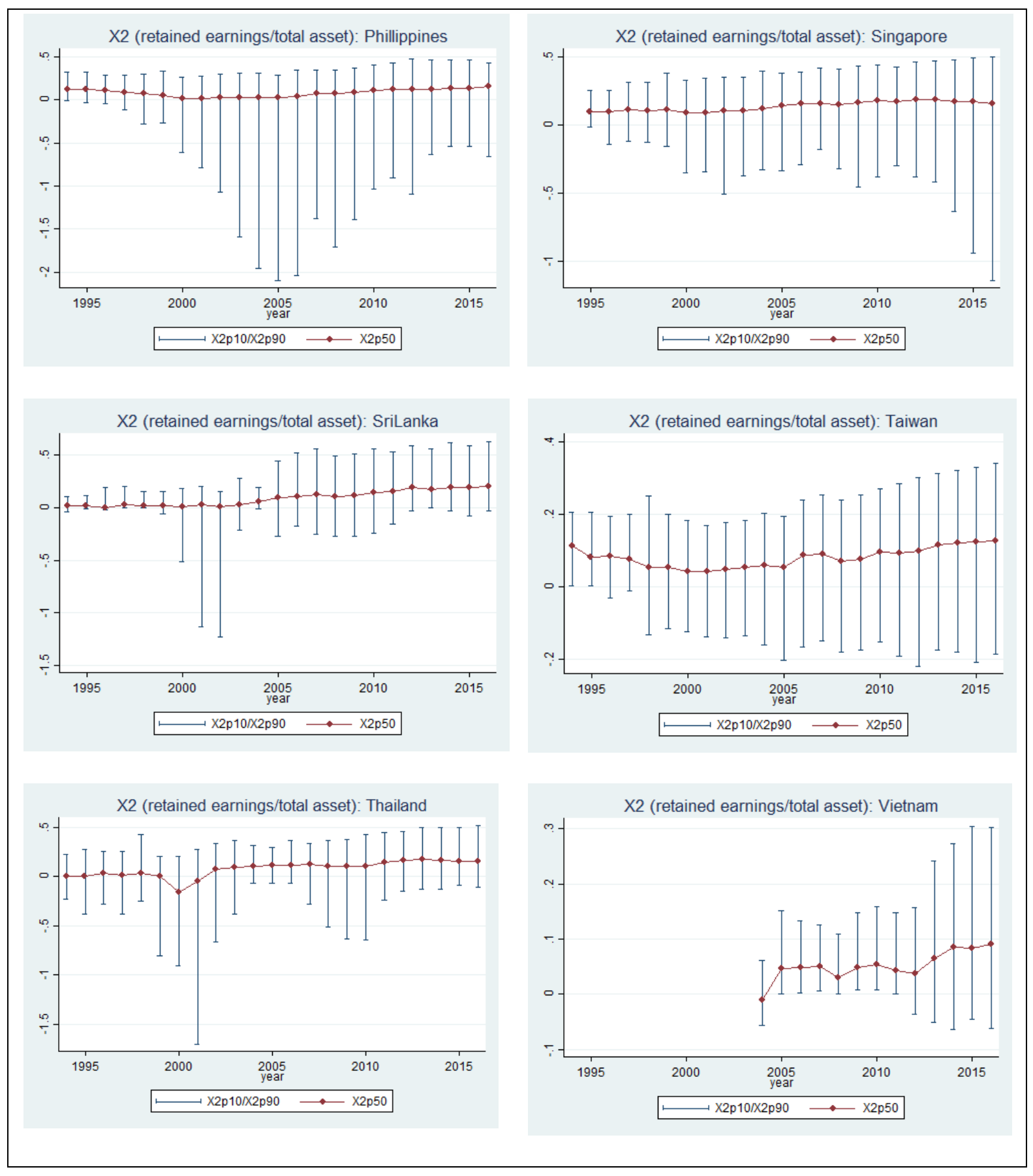




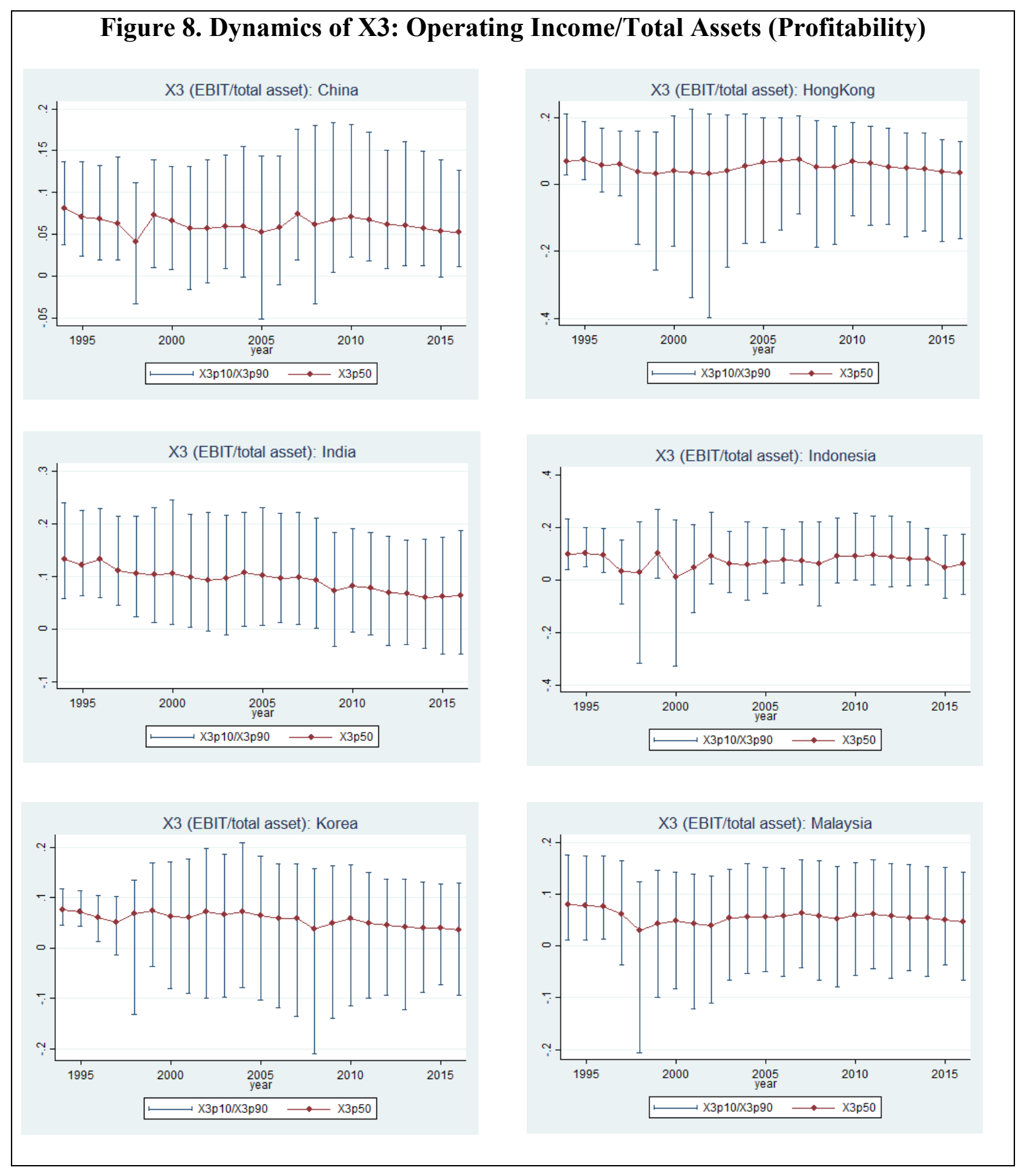




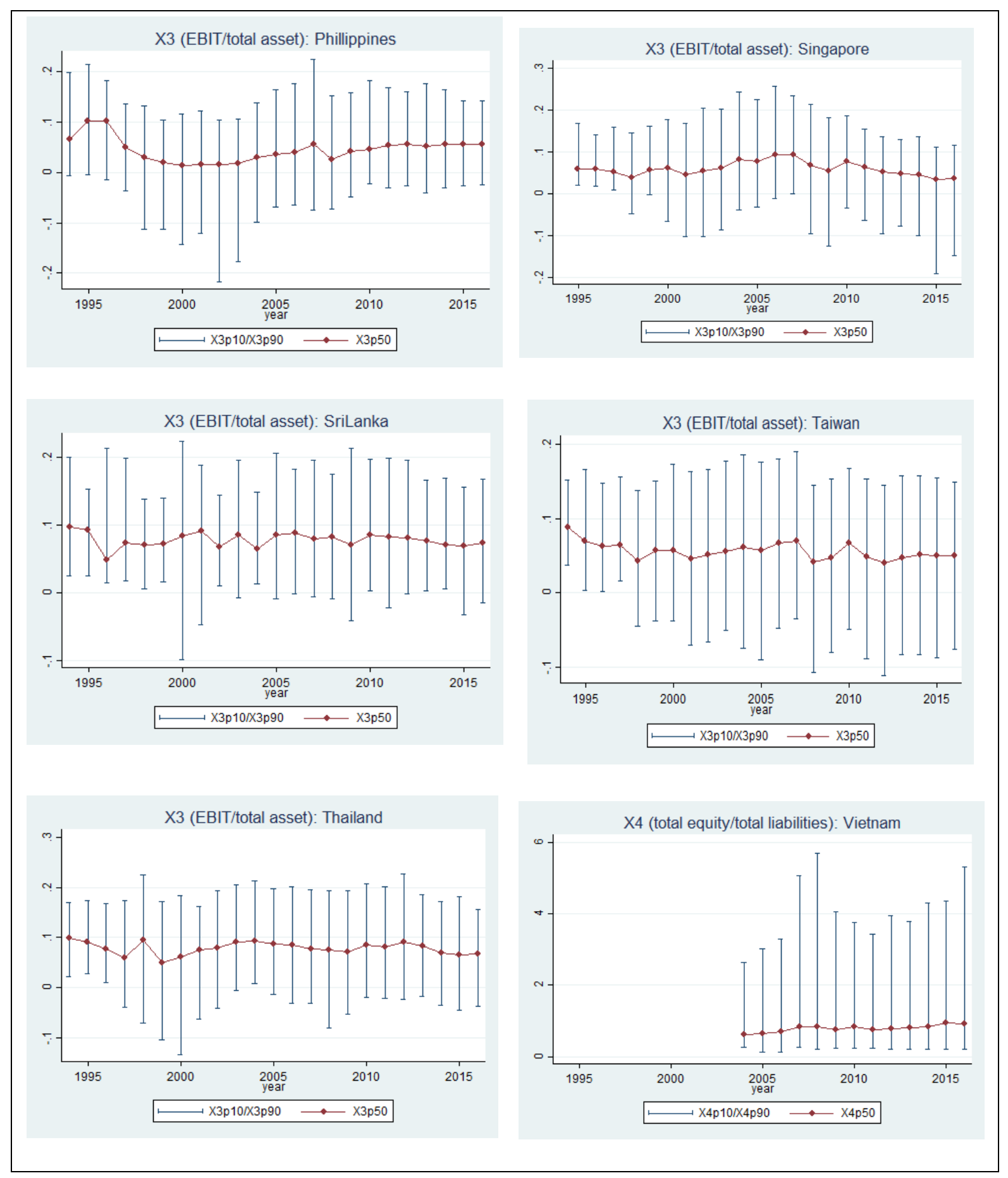




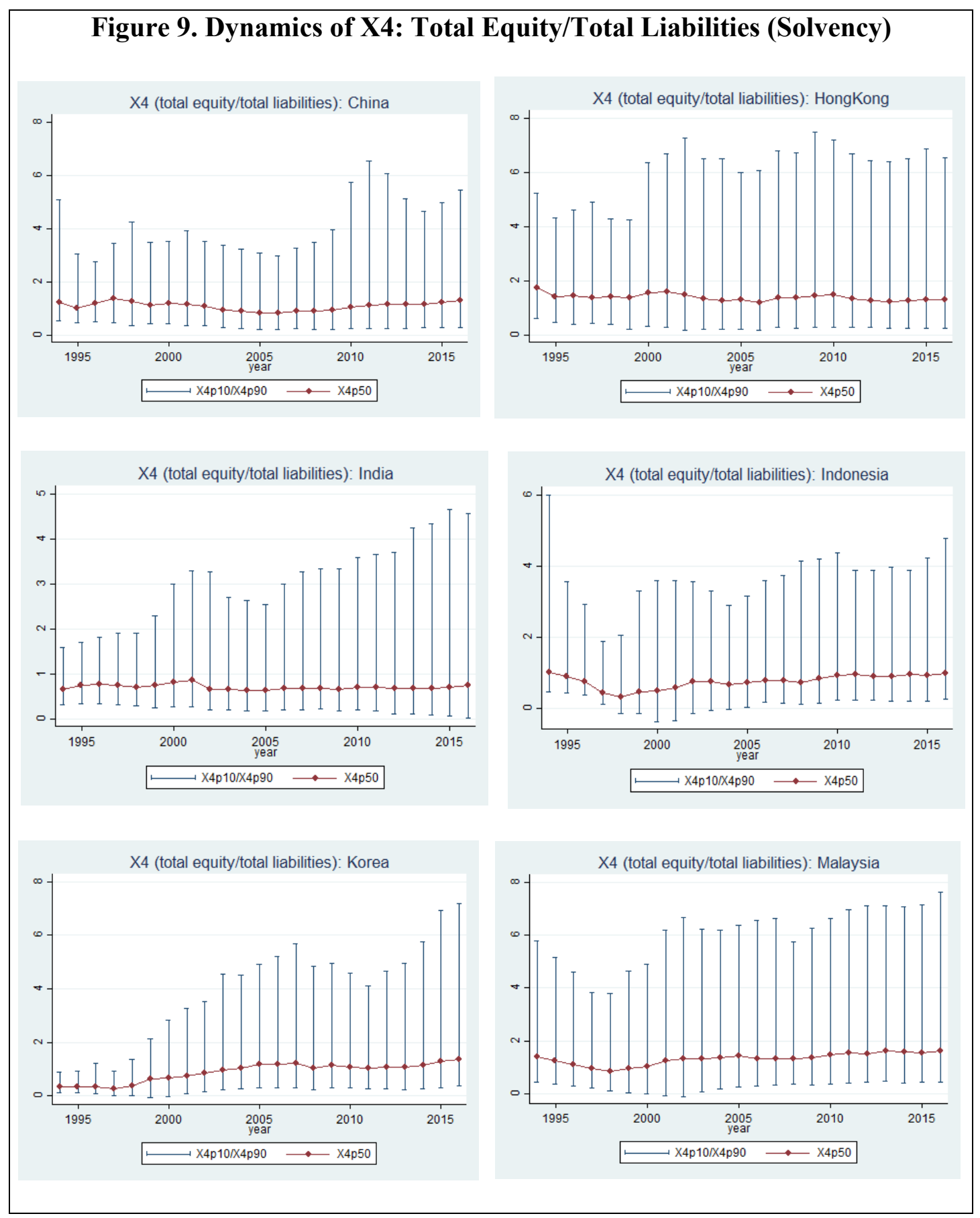




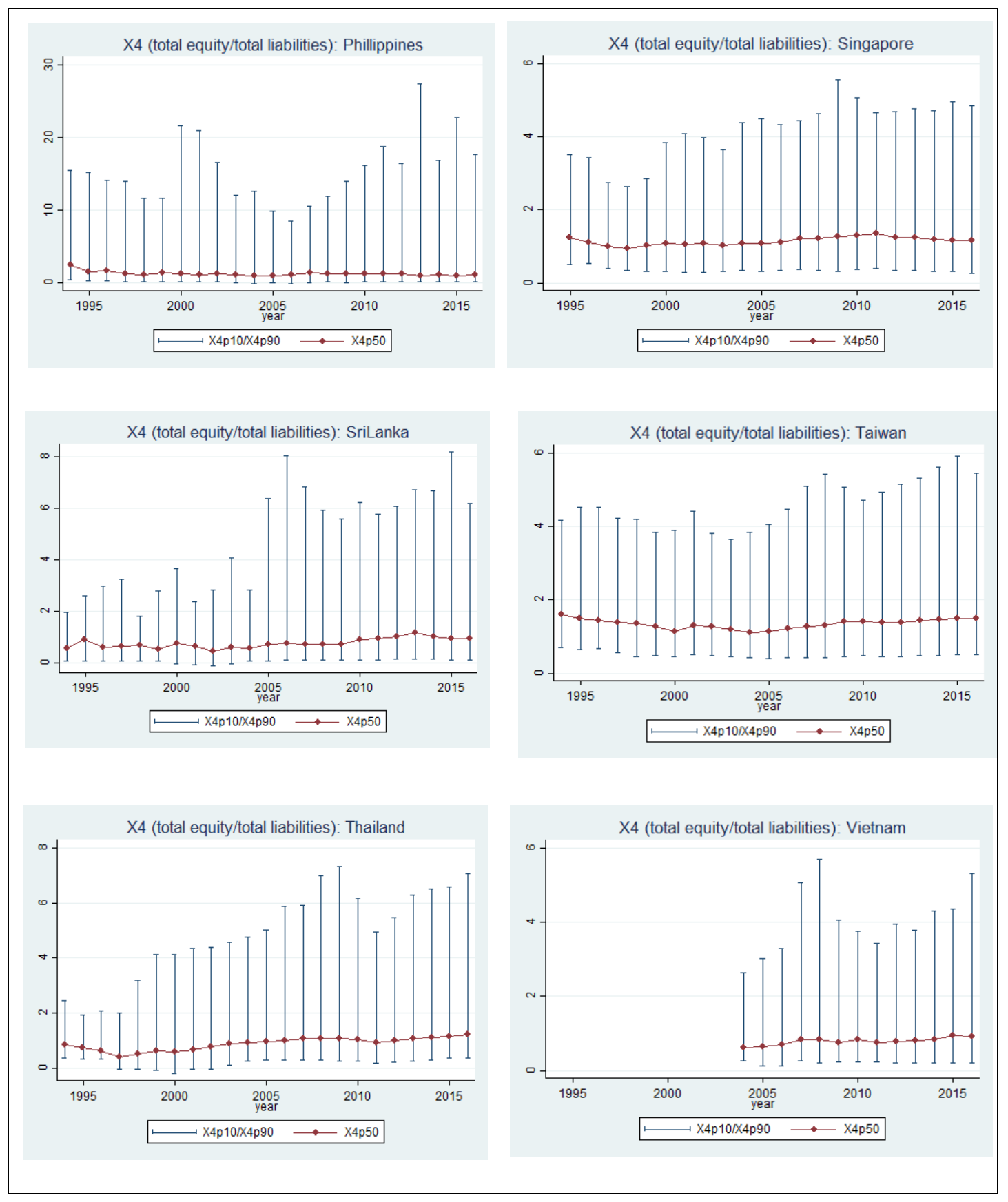




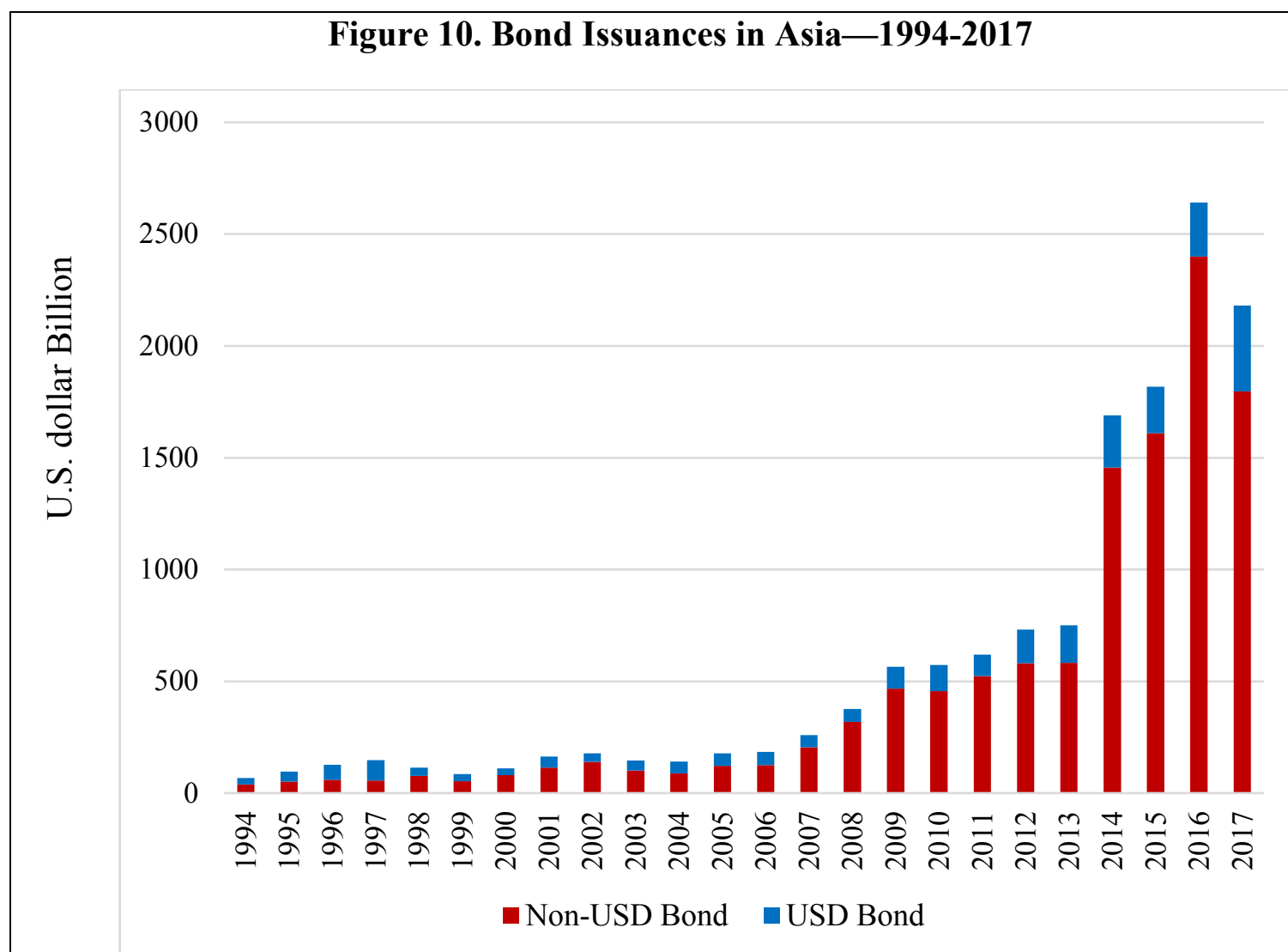

Sources: Thomson One Banker. (Each bar represents the amount of total issuance in the 12 Asian economies in a given year).

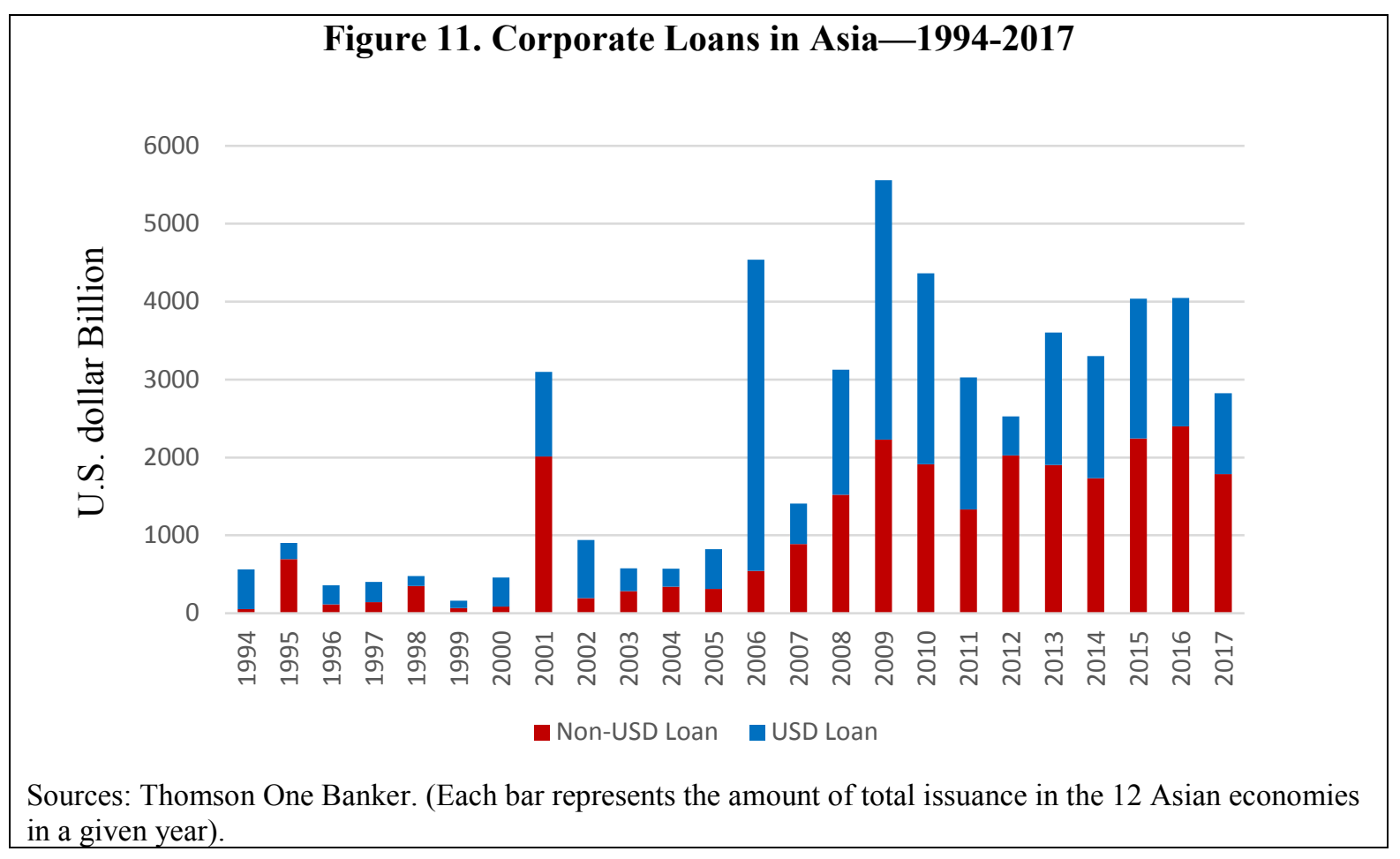

CInternational Monetary Fund. Not for Redistribution 
Figure 12: Maturity Dynamics of Syndicated Loan Issuance: Asia 1994-2017

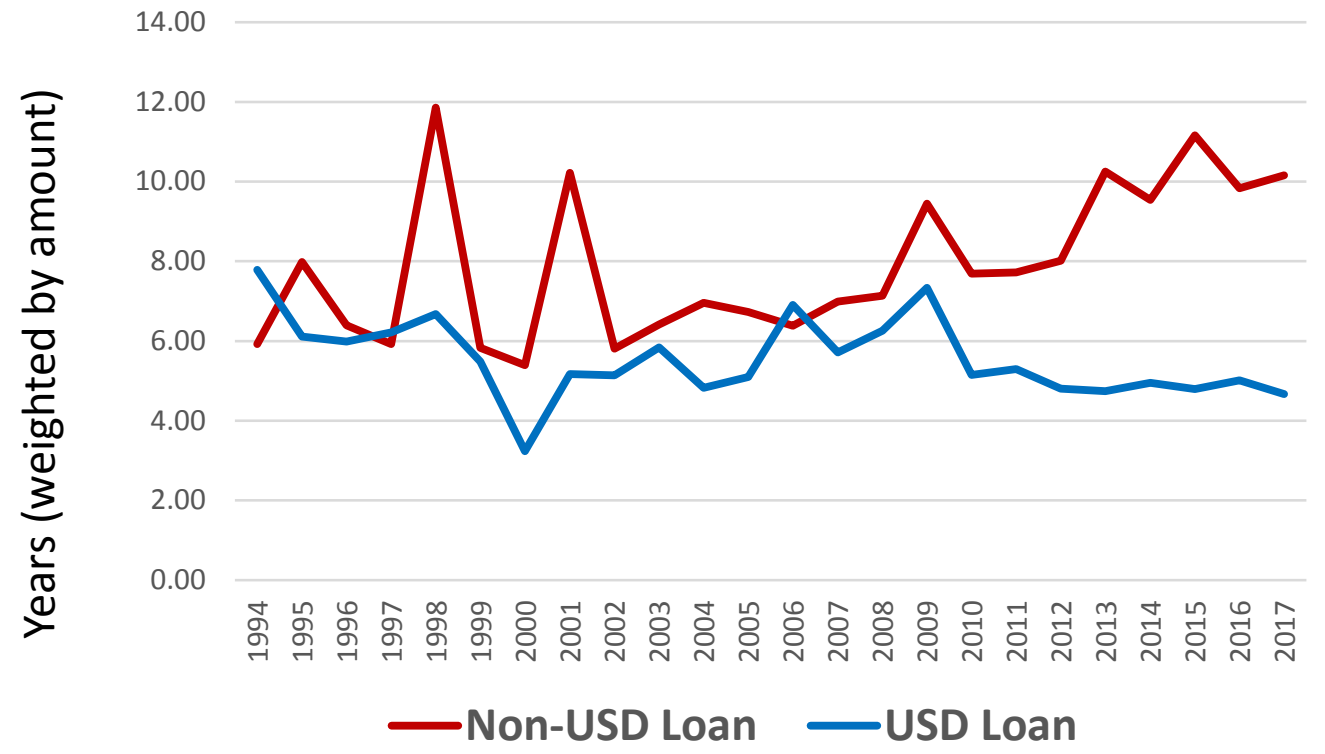

Sources: Thomson One Banker. Y-axis is the weighted (by dollar amount) average of syndicated loan maturity issued in a given year.

Figure 13: Maturity Dynamics of Bond Issuance: Asia 1994-2017

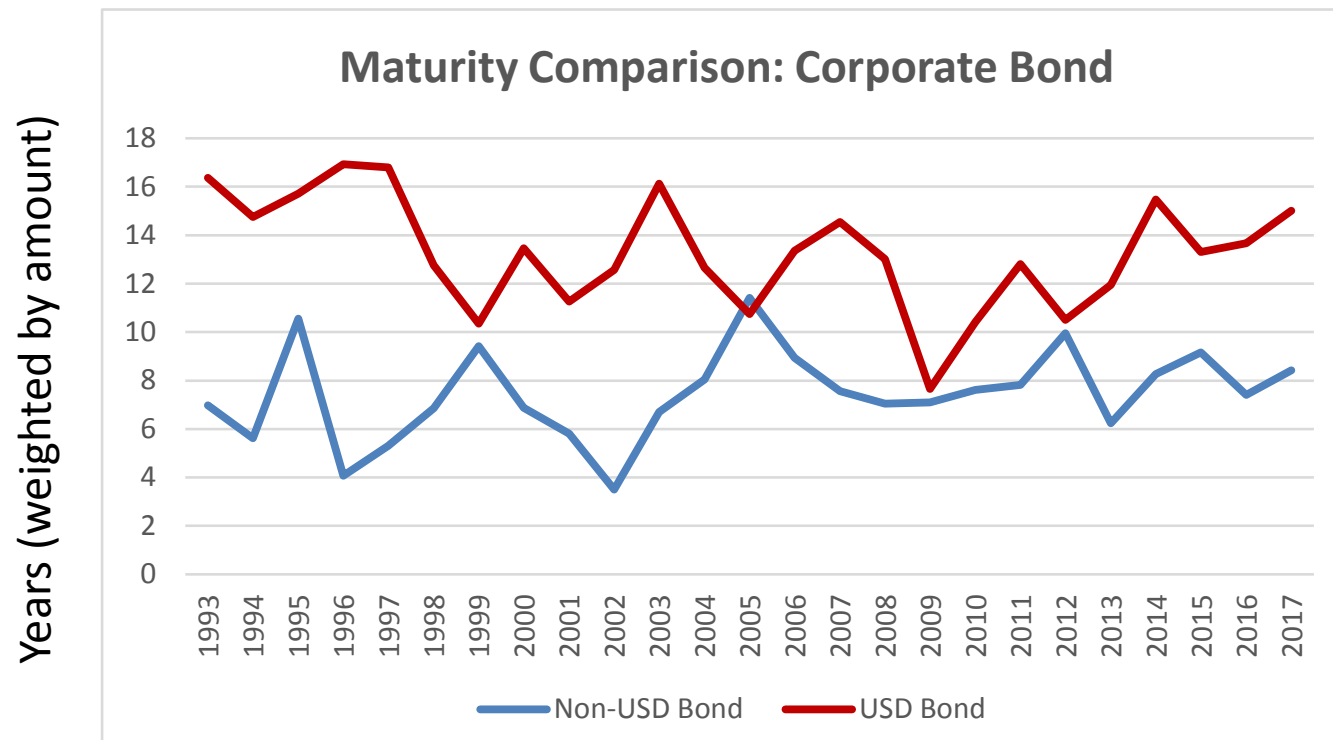

Sources: Thomson One Banker. Y-axis is the weighted (by dollar amount) average of corporate bond maturity issued in a given year. 
Figure 14: Distribution of Corporates' U.S. dollar Debt/Total Assets: Exporter/Nonexporter and Tradable sector/ Non-tradable sector
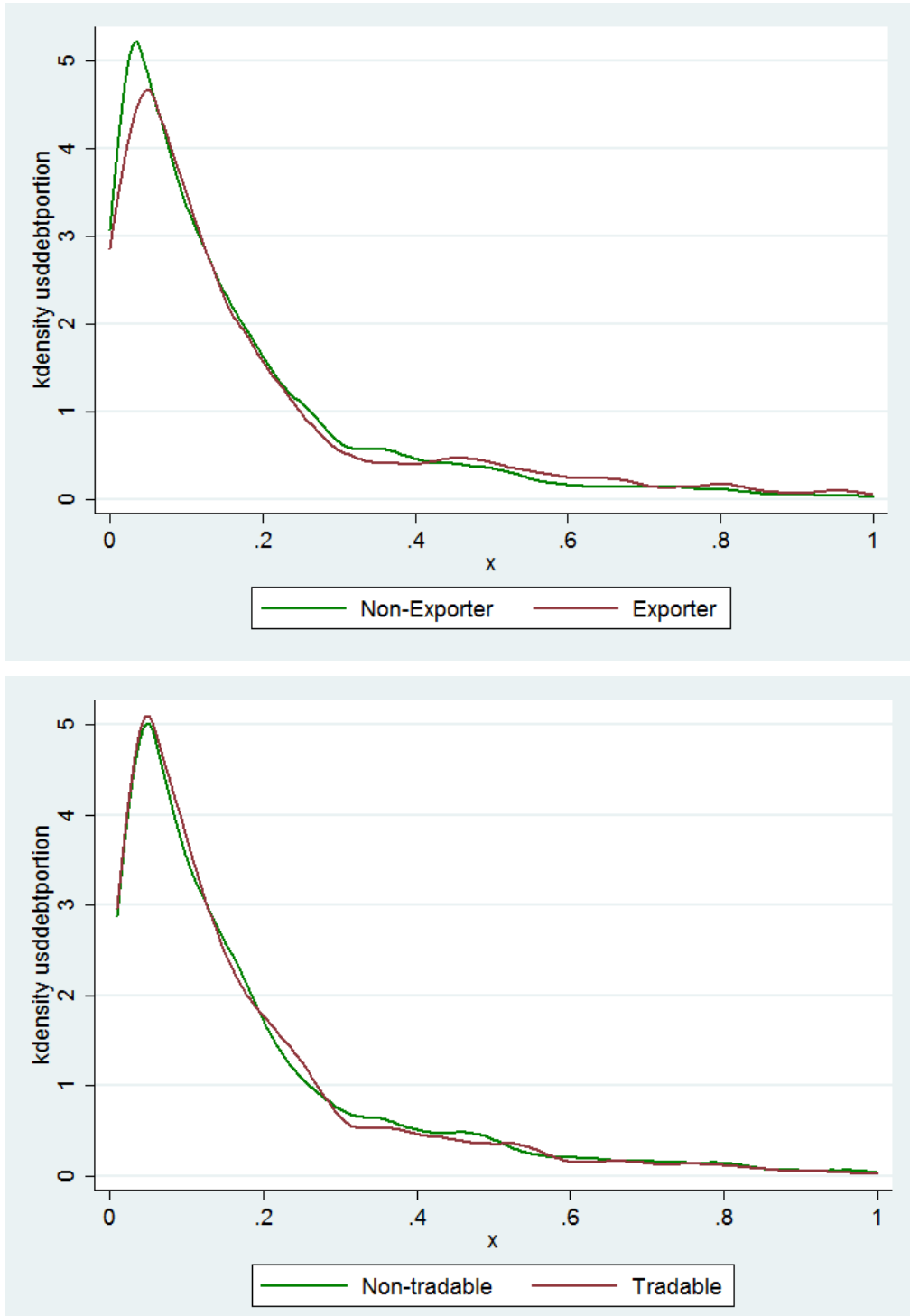

Source: Datastream Worldscope. A company is classified as an exporter if its Exports (WC07161) is nonnegative. A company is classified as in tradable sector if its SIC-code (WC07202) is between 2000 and 3999. The categorizations are based on Du and Schreger (2016) and the results are similar to their findings. 


\section{APPENDIX II. TABLES}

Table 1. Definition and Sources of the Variables

\begin{tabular}{|c|c|c|}
\hline Variables & Definition & Source \\
\hline $\begin{array}{l}\text { Delta Nominal U.S. } \\
\text { Exchange Rate }\end{array}$ & $\begin{array}{l}\text { (Nominal U.S. exchange rate(t)-Nominal U.S. exchange } \\
\operatorname{rate}(\mathrm{t}-1)) / \text { Nominal U.S. exchange rate }(\mathrm{t}-1)\end{array}$ & IMF WEO \\
\hline $\begin{array}{l}\text { Delta Real U.S. } \\
\text { Exchange Rate }\end{array}$ & $\begin{array}{l}\text { (Real U.S. exchange rate(t)-Real U.S. exchange rate(t- } \\
\text { 1))/Real U.S. exchange rate(t-1) }\end{array}$ & IMF WEO \\
\hline Delta NEER & $(\operatorname{NEER}(\mathrm{t})-\mathrm{NEER}(\mathrm{t}-1)) / \mathrm{NEER}(\mathrm{t}-1)$ & IMF WEO \\
\hline Delta REER & $(\operatorname{REER}(\mathrm{t})-\operatorname{REER}(\mathrm{t}-1)) / \operatorname{REER}(\mathrm{t}-1)$ & IMF WEO \\
\hline $\begin{array}{l}\text { Delta U.S. Shadow } \\
\text { Rate }\end{array}$ & $\begin{array}{l}\text { (U.S. Shadow Rate(t)-U.S. Shadow Rate(t-1))/U.S. } \\
\text { Shadow Rate(t-1) }\end{array}$ & Wu and Xia (2016) \\
\hline ROA & Net Income/Total Assets & Worldscope \\
\hline Leverage & Total Liability/Total Asset & Worldscope \\
\hline Tobin's Q & Total Market Value of firm/Total Book Value of firm & Worldscope \\
\hline Cash & Cash Holdings & Worldscope \\
\hline $\begin{array}{l}\text { U.S. dollar Debt } \\
\text { Portion }\end{array}$ & $\begin{array}{c}\text { (U.S. dollar loan+U.S. dollar bond)*Exchange } \\
\text { Rate/Total Asset }\end{array}$ & $\begin{array}{l}\text { Calculation based on } \\
\text { Thomson One and } \\
\text { Worldscope }\end{array}$ \\
\hline Z"-score & $\begin{array}{l}\text { Altman's } 2005 \mathrm{Z} \text { " score for emerging market firms: } \\
\qquad \begin{array}{c}Z "=3.25+6.56\left(X \_1\right)+3.26\left(X \_2\right)+6.72\left(X \_3\right. \\
)+1.05\left(X \_4\right)\end{array}\end{array}$ & $\begin{array}{l}\text { Calculation based on } \\
\text { Worldscope databease }\end{array}$ \\
\hline $\mathrm{X} 1$ & Working Capital/Total Asset & Worldscope \\
\hline $\mathrm{X} 2$ & Retained Earnings/Total Assets & Worldscope \\
\hline $\mathrm{X} 3$ & Operating Income (EBIT)/Total Assets & Worldscope \\
\hline $\mathrm{X} 4$ & Total Equity/Total Assets & Worldscope \\
\hline Exporter & $\begin{array}{l}\text { Dummy variable which equals } 1 \text { if the firm has } \\
\text { exporting income on balance sheet }\end{array}$ & Worldscope \\
\hline
\end{tabular}


Table 2 A: Summary Statistics for the Overall Sample

\begin{tabular}{|lrrrr|}
\hline \multicolumn{1}{r}{$\mathrm{N}$} & Mean & St. Dev & Median \\
\hline Z"-score & 200681 & 7.113 & 5.224 & 6.564 \\
ROA & 200681 & .044 & .141 & .049 \\
EBIT & 200681 & .05 & .162 & .059 \\
Leverage & 200681 & .468 & .265 & .455 \\
CAPEX & 199116 & .054 & .195 & .032 \\
Ln[Total Assets] & 200681 & 5.694 & 2.245 & 5.365 \\
Retained Earnings & & & & \\
& 200681 & .049 & .574 & .126 \\
Working Capital & & & & .171 \\
& 200681 & .178 & .278 & .07 \\
Cash & & & .125 & .289 \\
Employees & 163817 & .11 & .222 & .644 \\
Tangibility & 136938 & 5862.416 & 24453.73 & .516 \\
Tobin's Q & 200256 & .319 & .524 & .269 \\
Total Equity & 185191 & 1.245 & & \\
& 200681 & .507 & & \\
\hline
\end{tabular}

Table 2 B: Summary Statistics for the Subsample

\begin{tabular}{|c|c|c|c|c|}
\hline & $\mathrm{N}$ & Mean & St. Dev & Median \\
\hline$Z^{\prime \prime}$-score & 15614 & 5.881 & 8.204 & 5.775 \\
\hline ROA & 21493 & .054 & .123 & .054 \\
\hline EBIT & 21349 & .061 & .155 & .065 \\
\hline Leverage & 21463 & .426 & 1.327 & .402 \\
\hline CAPEX & 19960 & .077 & .181 & .042 \\
\hline Ln[Total Assets] & 21493 & 7.732 & 2.549 & 7.462 \\
\hline Retained Earnings & 16994 & .042 & .755 & .119 \\
\hline Working Capital & 19923 & .09 & .345 & .099 \\
\hline Cash & 20365 & .072 & .089 & .042 \\
\hline Employees & 15374 & 10670.77 & 34910.91 & 2828.5 \\
\hline Tangibility & 21461 & .388 & .239 & .38 \\
\hline Tobin's Q & 20584 & 1.025 & 1.436 & .756 \\
\hline Total Equity & 21493 & .409 & .348 & 421 \\
\hline USD bank loan & 8052 & 643.476 & 1128.363 & 150 \\
\hline USD bond & 2872 & 522.151 & 1616.578 & 300 \\
\hline Total USD debt & 9448 & 0.316 & 1.879 & 0.286 \\
\hline
\end{tabular}

Leverage is total liabilities divided by lagged total assets; CAPEX, EBIT, Retained Earnings, Working Capital, Cash, Total Equity and Total USD debt are all scaled by lagged total assets. Employees is the absolute number of employees of the firms. USD bank loan and USD bond are the face value of the firms' bond and bank loan issuance in million US. Tangibility is the book value of Properties, Plants and Equipment (PPE) divided by lagged total assets. Ln[Total Assets] is the natural log of total assets converted to USD. 
Table 3. Correlations Between Key Corporate Indicators

\begin{tabular}{|c|c|c|c|c|c|c|c|}
\hline & Z"-Score & Leverage & $\mathrm{ROA}$ & $\mathrm{ROE}$ & Current Ratio & ICR & Quick Ratio \\
\hline Z"-Score & 1 & & & & & & \\
\hline Leverage & $-0.296^{* * *}$ & 1 & & & & & \\
\hline $\mathrm{ROA}$ & $0.414^{* * *}$ & $-0.126^{* * *}$ & 1 & & & & \\
\hline $\mathrm{ROE}$ & $0.0901^{* * *}$ & $0.0547^{* * *}$ & $0.214^{* * *}$ & 1 & & & \\
\hline Current Ratio & $0.212^{* * *}$ & $-0.0520^{* * *}$ & $0.0339^{* * *}$ & 0.00528 & 1 & & \\
\hline ICR & $0.0247^{* *}$ & -0.0134 & $0.0207^{*}$ & 0.00181 & 0.00308 & 1 & \\
\hline Quick Ratio & $0.279^{* * *}$ & $-0.0661^{* * *}$ & $0.0520^{* * *}$ & 0.00687 & $0.952^{* * *}$ & 0.00408 & 1 \\
\hline
\end{tabular}

${ }^{*} p<0.05,{ }^{* *} p<0.01,{ }^{* * *} p<0.001$

Current Ratio=Current Assets/Total Liabilities; ICR=EBIT/Total Interest Expense; Quick

Ratio $=($ Cash + Marketable Securities + Account Receivables $) /$ Current Liabilities 
Table 4: Baseline Reults_-Nominal Exchange Rate

\begin{tabular}{|c|c|c|c|c|c|}
\hline VARIABLES & $\begin{array}{l}\text { (1) } \\
\text { Z'-score }\end{array}$ & $\begin{array}{l}(2) \\
\text { Z'-score }\end{array}$ & $\begin{array}{l}\text { (3) } \\
\text { Z'-score }\end{array}$ & $\begin{array}{l}(4) \\
\text { Z'-score }\end{array}$ & $\begin{array}{l}(5) \\
\text { Z'-score }\end{array}$ \\
\hline$\Delta$ Nominal Exchange Rate & $\begin{array}{l}1.355^{* * *} \\
(0.151)\end{array}$ & & & $\begin{array}{l}1.171 * * * \\
(0.156)\end{array}$ & $\begin{array}{l}1.365^{* * *} \\
(0.155)\end{array}$ \\
\hline$\Delta$ Short-term Interest Rate & & $\begin{array}{l}-0.000332 \\
(0.00249)\end{array}$ & & & $\begin{array}{l}-0.00190 \\
(0.00254)\end{array}$ \\
\hline$\Delta$ U.S Shadow Rate & & & $\begin{array}{l}-0.0257 * * * \\
(0.00320)\end{array}$ & $\begin{array}{l}-0.0260^{* * *} \\
(0.00333)\end{array}$ & \\
\hline VIX & & & & $\begin{array}{l}-0.00673^{* * *} \\
(0.00145)\end{array}$ & $\begin{array}{l}-0.00431^{* * *} \\
(0.00147)\end{array}$ \\
\hline Constant & $\begin{array}{l}7.117 * * * \\
(0.00808)\end{array}$ & $\begin{array}{l}7.129 * * * \\
(0.00856)\end{array}$ & $\begin{array}{l}7.069 * * * \\
(0.00863)\end{array}$ & $\begin{array}{l}7.204 * * * \\
(0.0299)\end{array}$ & $\begin{array}{l}7.216 * * * \\
(0.0305)\end{array}$ \\
\hline Observations & 200,681 & 187,726 & 184,888 & 184,888 & 187,726 \\
\hline R-squared & 0.571 & 0.561 & 0.578 & 0.578 & 0.561 \\
\hline Firm FE & Yes & Yes & Yes & Yes & Yes \\
\hline
\end{tabular}


Table 5: Baseline Reults-Real Exchange Rate

\begin{tabular}{|c|c|c|c|c|c|}
\hline VARIABLES & $\begin{array}{l}\text { (1) } \\
\text { Z'-score }\end{array}$ & $\begin{array}{l}\text { (2) } \\
\text { Z'-score }\end{array}$ & $\begin{array}{l}(3) \\
\text { Z'-score }\end{array}$ & $\begin{array}{l}\text { (4) } \\
\text { Z'-score }\end{array}$ & $\begin{array}{l}\text { (5) } \\
\text { Z"-score }\end{array}$ \\
\hline$\Delta$ Real Exchange Rate & $\begin{array}{l}1.267^{* * *} \\
(0.144)\end{array}$ & & & $\begin{array}{l}1.055^{* * *} \\
(0.150)\end{array}$ & $\begin{array}{l}1.285^{* * *} \\
(0.149)\end{array}$ \\
\hline$\Delta$ Short-term Interest Rate & & $\begin{array}{l}-0.000332 \\
(0.00249)\end{array}$ & & & $\begin{array}{l}-0.00160 \\
(0.00254)\end{array}$ \\
\hline$\Delta$ U.S. Shadow Rate & & & $\begin{array}{l}-0.0257 * * * \\
(0.00320)\end{array}$ & $\begin{array}{l}-0.0258^{* * *} \\
(0.00334)\end{array}$ & \\
\hline VIX & & & & $\begin{array}{l}-0.00724^{* * * *} \\
(0.00145)\end{array}$ & $\begin{array}{l}-0.00465^{* * *} \\
(0.00146)\end{array}$ \\
\hline Constant & $\begin{array}{l}7.107 * * * \\
(0.00810)\end{array}$ & $\begin{array}{l}7.129 * * * \\
(0.00856)\end{array}$ & $\begin{array}{l}7.069 * * * \\
(0.00863)\end{array}$ & $\begin{array}{l}7.206 * * * \\
(0.0299)\end{array}$ & $\begin{array}{l}7.216^{* * *} \\
(0.0305)\end{array}$ \\
\hline Observations & 200,681 & 187,726 & 184,888 & 184,888 & 187,726 \\
\hline R-squared & 0.571 & 0.561 & 0.578 & 0.578 & 0.561 \\
\hline Firm FE & Yes & Yes & Yes & Yes & Yes \\
\hline
\end{tabular}

Standard errors in parentheses

$* * * \mathrm{p}<0.01, * * \mathrm{p}<0.05,{ }^{*} \mathrm{p}<0.1$

This table regresses the firms level Z' 'score on percentage changes in real exchange rates, the domestic shortterm interest rate, U.S. shadow rates, and the level of VIX as a measure of global risk attitude. Country-time fixed effects are directly absorbed into changes in nominal exchange rate and short-term interest rate. 
Table 6: Baseline Results-NEER

\begin{tabular}{|c|c|c|c|c|c|}
\hline VARIABLES & $\begin{array}{l}\text { (1) } \\
\text { Z'-score }\end{array}$ & $\begin{array}{l}(2) \\
\text { Z'-score }\end{array}$ & $\begin{array}{l}\text { (3) } \\
\text { Z'-score }\end{array}$ & $\begin{array}{l}\text { (4) } \\
\text { Z'-score }\end{array}$ & $\begin{array}{l}\text { (5) } \\
\text { Z'-score }\end{array}$ \\
\hline$\triangle$ NEER & $\begin{array}{l}0.768 * * * \\
(0.157)\end{array}$ & & & $\begin{array}{l}0.694 * * * \\
(0.168)\end{array}$ & $\begin{array}{l}0.751^{* * *} \\
(0.168)\end{array}$ \\
\hline $\begin{array}{l}\Delta \text { Short-term Interest } \\
\text { Rate }\end{array}$ & & -0.000332 & & & -0.00192 \\
\hline$\Delta$ U.S. Shadow Rate & & $(0.00249)$ & $\begin{array}{l}-0.0257 * * * \\
(0.00320)\end{array}$ & $\begin{array}{l}-0.0284 * * * \\
(0.00331)\end{array}$ & $(0.00254)$ \\
\hline VIX & & & & $\begin{array}{l}-0.006411^{* * *} \\
(0.00149)\end{array}$ & $\begin{array}{l}-0.00362^{* *} \\
(0.00149)\end{array}$ \\
\hline Constant & $\begin{array}{l}7.114 * * * \\
(0.00807)\end{array}$ & $\begin{array}{l}7.129 * * * \\
(0.00856)\end{array}$ & $\begin{array}{l}7.069 * * * \\
(0.00863)\end{array}$ & $\begin{array}{l}7.195^{* * *} \\
(0.0306)\end{array}$ & $\begin{array}{l}7.202 * * * \\
(0.0310)\end{array}$ \\
\hline Observations & 200,681 & 187,726 & 184,888 & 184,888 & 187,726 \\
\hline R-squared & 0.571 & 0.561 & 0.578 & 0.578 & 0.561 \\
\hline Firm FE & Yes & Yes & Yes & Yes & Yes \\
\hline
\end{tabular}

This table regresses the firms level Z"'-score on percentage changes in nominal effective exchange rates, the domestic short-term interest rate, U.S. shadow rates, and the level of VIX as a measure of global risk attitude. Country-time fixed effects are directly absorbed into changes in nominal exchange rate and short-term interest rate. 
Table 7: Baseline Reults—REER

\begin{tabular}{|c|c|c|c|c|c|}
\hline VARIABLES & $\begin{array}{l}(1) \\
\text { Z''-score }\end{array}$ & $\begin{array}{l}(2) \\
\text { Z''-score }\end{array}$ & $\begin{array}{l}(3) \\
Z \text { ''-score }\end{array}$ & $\begin{array}{l}(4) \\
\text { Z''-score }\end{array}$ & $\begin{array}{l}(5) \\
\text { Z''-score }\end{array}$ \\
\hline$\triangle$ NEER & $\begin{array}{l}0.523 * * * \\
(0.153)\end{array}$ & & & $\begin{array}{l}0.394 * * \\
(0.163)\end{array}$ & $\begin{array}{l}0.464 * * * \\
(0.162)\end{array}$ \\
\hline $\begin{array}{l}\Delta \text { Short-term Interest } \\
\text { Rate }\end{array}$ & & -0.000332 & & & -0.00194 \\
\hline$\Delta$ U.S. Shadow Rate & & $(0.00249)$ & $\begin{array}{l}-0.0257 * * * \\
(0.00320)\end{array}$ & $\begin{array}{l}-0.0290 * * * \\
(0.00331)\end{array}$ & $(0.00254)$ \\
\hline VIX & & & & $\begin{array}{l}-0.00713 * * * \\
(0.00148)\end{array}$ & $\begin{array}{l}-0.00413 * * * \\
(0.00149)\end{array}$ \\
\hline Constant & $\begin{array}{l}7.109 * * * \\
(0.00814)\end{array}$ & $\begin{array}{l}7.129 * * * \\
(0.00856)\end{array}$ & $\begin{array}{l}7.069 * * * \\
(0.00863)\end{array}$ & $\begin{array}{l}7.206 * * * \\
(0.0307)\end{array}$ & $\begin{array}{l}7.209 * * * \\
(0.0311)\end{array}$ \\
\hline Observations & 200,681 & 187,726 & 184,888 & 184,888 & 187,726 \\
\hline R-squared & 0.571 & 0.561 & 0.578 & 0.578 & 0.561 \\
\hline Firm FE & Yes & Yes & Yes & Yes & Yes \\
\hline
\end{tabular}

This table regresses the firms level Z' -score on percentage changes in real effective exchange rates, the domestic short-term interest rate, U.S. shadow rates, and the level of VIX as a measure of global risk attitude. Country-time fixed effects are directly absorbed into changes in nominal exchange rate and short-term interest rate. 
Table 8. Currency Decomposition-Nominal Exchange Rate

\begin{tabular}{|c|c|c|c|c|c|c|c|c|c|c|}
\hline & $\begin{array}{l}(1) \\
7, ' \text {-score }\end{array}$ & $\begin{array}{l}(2) \\
7, \text {-score }\end{array}$ & $\begin{array}{l}(3) \\
7 \text { ",-score }\end{array}$ & $\begin{array}{l}(4) \\
\text { Z''-score }\end{array}$ & $\begin{array}{l}(5) \\
Z, ' \text {-score }\end{array}$ & $\begin{array}{l}(6) \\
Z, ' \text {-score }\end{array}$ & $\begin{array}{l}(7) \\
\text { Z"'-score }\end{array}$ & $\begin{array}{l}(8) \\
Z, ' \text {-score }\end{array}$ & $\begin{array}{l}(9) \\
Z, ' \text {-score }\end{array}$ & $\begin{array}{l}(10) \\
Z, ' \text {-score }\end{array}$ \\
\hline VARIABLES & & & & & & & & & & \\
\hline \multirow[t]{2}{*}{$\Delta$ Nominal Exchange Rate } & $2.369^{* * *}$ & & & 1.329 & $1.219 * *$ & 1.273 & $2.339 * * *$ & $2.151 * * *$ & $2.469 * * *$ & $2.109 * * *$ \\
\hline & $(0.805)$ & & & $(0.893)$ & $(0.605)$ & $(0.915)$ & $(0.819)$ & $(0.822)$ & $(0.829)$ & $(0.545)$ \\
\hline \multirow[t]{2}{*}{ U.S. dollar Debt Portion } & -0.0450 & -0.0161 & -0.0455 & $-0.165^{*}$ & $-0.0829 *$ & -0.124 & 0.00891 & 0.00775 & -0.00545 & -0.00552 \\
\hline & $(0.0886)$ & $(0.0394)$ & $(0.0906)$ & $(0.0992)$ & $(0.0444)$ & $(0.102)$ & $(0.0914)$ & $(0.0913)$ & $(0.0421)$ & $(0.0420)$ \\
\hline \multirow[t]{2}{*}{$\Delta$ Short-term Interest Rate } & & 0.00143 & & & & -0.00667 & 0.0120 & 0.00336 & & \\
\hline & & $(0.0150)$ & & & & $(0.0154)$ & $(0.0159)$ & $(0.0162)$ & & \\
\hline \multirow[t]{2}{*}{$\Delta$ U.S. Shadow Rate } & & & $-0.111 * * *$ & & $-0.104 * * *$ & & & & $-0.0863 * * *$ & $-0.0989 * * *$ \\
\hline & & & $(0.0165)$ & & $(0.0167)$ & & & & $(0.0169)$ & $(0.0174)$ \\
\hline \multirow{2}{*}{$\begin{array}{l}\text { U.S. dollar Debt Portion* } \Delta \text { Nominal } \\
\text { Exchange Rate }\end{array}$} & & & & $3.949^{* * *}$ & $3.322 * * *$ & $3.417 * *$ & & & & \\
\hline & & & & $(1.471)$ & $(0.985)$ & $(1.524)$ & & & & \\
\hline \multirow[t]{2}{*}{ VIX } & & & & & $-0.0213 * * *$ & $-0.0265 * *$ & & $-0.0267 * * *$ & & $-0.0212 * * *$ \\
\hline & & & & & $(0.00683)$ & $(0.0103)$ & & $(0.0103)$ & & $(0.00683)$ \\
\hline \multirow{2}{*}{$\begin{array}{l}\text { U.S. dollar Debt Portion* } \Delta \text { Short-term } \\
\text { Interest Rate }\end{array}$} & & & & & & & $-0.114^{*}$ & $-0.114 * *$ & & \\
\hline & & & & & & & $(0.0581)$ & $(0.0580)$ & & \\
\hline \multirow{2}{*}{$\begin{array}{l}\text { U.S. dollar Debt Portion* } \Delta \text { U.S. Shadow } \\
\text { Rate }\end{array}$} & & & & & & & & & -0.0296 & -0.0316 \\
\hline & & & & & & & & & $(0.0564)$ & $(0.0564)$ \\
\hline \multirow[t]{2}{*}{ Constant } & $5.906^{* * *}$ & $5.902 * * *$ & $4.892 * * *$ & $5.919 * * *$ & $5.343 * * *$ & $6.462 * * *$ & $5.915^{* * *}$ & $6.455^{* * *}$ & $4.910 * * *$ & $5.330 * * *$ \\
\hline & $(0.0584)$ & $(0.0608)$ & $(0.0412)$ & $(0.0586)$ & $(0.141)$ & $(0.217)$ & $(0.0610)$ & $(0.217)$ & $(0.0409)$ & $(0.141)$ \\
\hline Observations & 15,614 & 15,047 & 14,545 & 15,614 & 14,545 & 15,047 & 15,047 & 15,046 & 14,545 & 14,545 \\
\hline R-squared & 0.306 & 0.304 & 0.306 & 0.307 & 0.307 & 0.305 & 0.305 & 0.305 & 0.306 & 0.306 \\
\hline Firm FE & Yes & Yes & Yes & Yes & Yes & Yes & Yes & Yes & Yes & Yes \\
\hline
\end{tabular}

Table 8 uses the subsample of firms that have ever issued USD debt. The dependent variable is the firm-level Z''-score, and the independent variables include the proportion of USD debt on firms' balance sheet (scaled by lagged total assets). We control for firms' fixed effects. Column (1)-(3) regress Z' -score on USD debt and one of the three macro-finance condition variables (nominal exchange rates, short-term interest rate and U.S. shadow rate) separately. We interect the USD debt portion with changes in nominal exchange rate (column (4)-(6)), changes in short-term interest rate (column (7)-(8)) and changes in U.S. shadow rate (column (9)-(10)). 
Table 9. Currency Decomposition-Real Exchange Rate

\begin{tabular}{|c|c|c|c|c|c|c|c|c|c|c|c|}
\hline VARIABLES & $\begin{array}{l}(1) \\
Z \prime,- \\
\text { score } \\
\end{array}$ & $\begin{array}{l}(2) \\
Z ',- \\
\text { score } \\
\end{array}$ & $\begin{array}{l}(3) \\
Z \prime \prime- \\
\text { score } \\
\end{array}$ & $\begin{array}{l}(4) \\
Z ',- \\
\text { score } \\
\end{array}$ & $\begin{array}{l}(5) \\
Z ',- \\
\text { score } \\
\end{array}$ & $\begin{array}{l}(6) \\
Z \text { '-score }\end{array}$ & $\begin{array}{l}(7) \\
Z \text { ',-score }\end{array}$ & $\begin{array}{l}(8) \\
Z ',- \\
\text { score } \\
\end{array}$ & $\begin{array}{l}(9) \\
Z \text { ''-score }\end{array}$ & $\begin{array}{l}(10) \\
Z, '- \\
\text { score } \\
\end{array}$ & $\begin{array}{l}(11) \\
Z \text { ''-score }\end{array}$ \\
\hline$\Delta$ Real Exchange Rate & $\begin{array}{l}1.911 * * \\
(0.783)\end{array}$ & & & & $\begin{array}{l}1.204 \\
(0.877)\end{array}$ & $\begin{array}{l}1.153 \\
(0.856)\end{array}$ & $\begin{array}{l}1.076 \\
(0.895)\end{array}$ & $\begin{array}{l}1.921 * * \\
(0.796)\end{array}$ & $\begin{array}{l}1.764 * * \\
(0.798)\end{array}$ & $\begin{array}{l}1.925 * * \\
(0.807)\end{array}$ & $\begin{array}{l}1.693 * * \\
(0.812)\end{array}$ \\
\hline U.S. dollar Debt Portion & $\begin{array}{l}-0.0468 \\
(0.0886)\end{array}$ & $\begin{array}{l}-0.0210 \\
(0.0904)\end{array}$ & $\begin{array}{l}-0.0455 \\
(0.0906)\end{array}$ & $\begin{array}{l}-0.0180 \\
(0.0920)\end{array}$ & $\begin{array}{l}-0.0946 \\
(0.0925)\end{array}$ & $\begin{array}{l}-0.0806 \\
(0.0948)\end{array}$ & $\begin{array}{l}-0.0671 \\
(0.0944)\end{array}$ & $\begin{array}{l}0.00737 \\
(0.0914)\end{array}$ & $\begin{array}{l}0.00631 \\
(0.0913)\end{array}$ & $\begin{array}{l}-0.0378 \\
(0.0968)\end{array}$ & $\begin{array}{l}-0.0377 \\
(0.0968)\end{array}$ \\
\hline$\Delta$ Short-term Interest Rate & & $\begin{array}{l}0.00143 \\
(0.0150)\end{array}$ & & $\begin{array}{l}-0.00344 \\
(0.0155)\end{array}$ & & & $\begin{array}{l}-0.00677 \\
(0.0154)\end{array}$ & $\begin{array}{l}0.0126 \\
(0.0159)\end{array}$ & $\begin{array}{l}0.00363 \\
(0.0162)\end{array}$ & & \\
\hline$\Delta$ U.S. Shadow Rate & & & $\begin{array}{l}0.00297 \\
(0.0246)\end{array}$ & $\begin{array}{l}0.00309 \\
(0.0251)\end{array}$ & & $\begin{array}{l}-0.00456 \\
(0.0256)\end{array}$ & & & & $\begin{array}{l}0.0127 \\
(0.0260)\end{array}$ & $\begin{array}{l}-0.00327 \\
(0.0267)\end{array}$ \\
\hline U.S. dollar Debt Portion* $\Delta$ Real Exchange Rate & & & & & $\begin{array}{l}3.003 * \\
(1.680)\end{array}$ & $\begin{array}{l}2.334 \\
(1.711)\end{array}$ & $\begin{array}{l}2.980 * \\
(1.710)\end{array}$ & & & & \\
\hline VIX & & & & & & $\begin{array}{l}0.0260 * * \\
(0.0105)\end{array}$ & $\begin{array}{l}0.0274 * * * \\
(0.0103)\end{array}$ & & $\begin{array}{l}- \\
0.0274 * * * \\
(0.0103)\end{array}$ & & $\begin{array}{l}-0.0268 * * \\
(0.0105)\end{array}$ \\
\hline U.S. dollar Debt Portion* $\Delta$ Short-term Interest Rate & & & & & & & & $\begin{array}{l}-0.114^{* *} \\
(0.0581)\end{array}$ & $\begin{array}{l}-0.115^{* *} \\
(0.0580)\end{array}$ & & \\
\hline U.S. dollar Debt Portion* $\Delta$ U.S. Shadow Rate & & & & & & & & & & $\begin{array}{l}-0.0141 \\
(0.0865)\end{array}$ & $\begin{array}{l}-0.0167 \\
(0.0865)\end{array}$ \\
\hline Constant & $\begin{array}{l}5.884 * * \\
* \\
(0.0581)\end{array}$ & $\begin{array}{l}5.902 * * \\
* \\
(0.0608)\end{array}$ & $\begin{array}{l}5.866 * * \\
* \\
(0.0623)\end{array}$ & $\begin{array}{l}5.881 * * \\
* \\
(0.0646)\end{array}$ & $\begin{array}{l}5.891 * * \\
* \\
(0.0582)\end{array}$ & $\begin{array}{l}6.403 * * * \\
(0.217)\end{array}$ & $\begin{array}{l}6.460 * * * \\
(0.218)\end{array}$ & $\begin{array}{l}5.896 * * \\
* \\
(0.0608)\end{array}$ & $\begin{array}{l}6.451 * * * \\
(0.217)\end{array}$ & $\begin{array}{l}5.865 * * \\
* \\
(0.0623)\end{array}$ & $\begin{array}{l}6.397 * * * \\
(0.217)\end{array}$ \\
\hline $\begin{array}{l}\text { Observations } \\
\text { R-squared } \\
\text { Firm FE }\end{array}$ & $\begin{array}{l}15,614 \\
0.306 \\
\text { Yes }\end{array}$ & $\begin{array}{l}15,047 \\
0.304 \\
\text { Yes }\end{array}$ & $\begin{array}{l}14,546 \\
0.306 \\
\text { Yes }\end{array}$ & $\begin{array}{l}14,546 \\
0.304 \\
\text { Yes }\end{array}$ & $\begin{array}{l}15,614 \\
0.306 \\
\text { Yes }\end{array}$ & $\begin{array}{l}14,546 \\
0.306 \\
\text { Yes }\end{array}$ & $\begin{array}{l}15,047 \\
0.305 \\
\text { Yes }\end{array}$ & $\begin{array}{l}15,047 \\
0.305 \\
\text { Yes }\end{array}$ & $\begin{array}{l}15,047 \\
0.305 \\
\text { Yes }\end{array}$ & $\begin{array}{l}14,546 \\
0.306 \\
\text { Yes }\end{array}$ & $\begin{array}{l}14,546 \\
0.306 \\
\text { Yes }\end{array}$ \\
\hline
\end{tabular}

Table 9 uses the subsample of firms that have ever issued USD debt. The dependent variable is the firm-level Z'-score, and the independent variables include the proportion of USD debt on firms' balance sheet (scaled by lagged total assets). We control for firms' fixed effects. Column (1)-(3) regress Z"'-score on USD debt and one of the three macro-finance condition variables (real exchange rates, short-term interest rate and U.S. shadow rate) separately. Column (4) include both the short-term interest rate and U.S. shadow rate while controling for USD debtportion. We interect the USD debt portion with changes in real exchange rate (column (5)-(7)), changes in short-term interest rate (column (8)-(9)) and changes in U.S. shadow rate (column (10)-(11)). 
Table 10. Corporate VuInerability-Quantile Regressions

\begin{tabular}{|c|c|c|c|c|c|c|}
\hline VARIABLES & $\begin{array}{c}(1) \\
Z^{\prime} \text {-score } \\
\end{array}$ & $\begin{array}{c}(2) \\
Z^{\prime \prime} \text {-score }\end{array}$ & $\begin{array}{c}(3) \\
Z^{\prime \prime} \text {-score }\end{array}$ & $\begin{array}{c}(4) \\
Z^{\prime \prime}-\text { score } \\
\end{array}$ & $\begin{array}{c}(5) \\
Z^{\prime \prime} \text {-score }\end{array}$ & $\begin{array}{c}(6) \\
Z^{\prime \prime} \text {-score }\end{array}$ \\
\hline USD debt portion & $\begin{array}{l}-5.355 \\
(5.181)\end{array}$ & $\begin{array}{c}-10.54 * \\
(6.046)\end{array}$ & $\begin{array}{l}-11.10 \\
(7.267)\end{array}$ & $\begin{array}{l}12.02 * \\
(4.981)\end{array}$ & $\begin{array}{l}4.722 * \\
(2.639)\end{array}$ & $\begin{array}{c}6.0516 \\
(10.136)\end{array}$ \\
\hline$\Delta$ Nominal Exchange Rate & $\begin{array}{c}-0.354 * * \\
(0.123)\end{array}$ & $\begin{array}{c}-2.210^{* * * *} \\
(0.698)\end{array}$ & $\begin{array}{c}-2.207 * * \\
(0.763)\end{array}$ & $\begin{array}{c}2.019 \\
(1.319)\end{array}$ & $\begin{array}{l}3.236^{*} \\
(1.487)\end{array}$ & $\begin{array}{l}3.613 * * \\
(1.231)\end{array}$ \\
\hline$\Delta$ U.S. shadow rate & $\begin{array}{l}-0.0133 \\
(0.0376)\end{array}$ & $\begin{array}{l}-0.00277 \\
(0.0178)\end{array}$ & $\begin{array}{c}-0.0936^{* * *} \\
(0.0346)\end{array}$ & $\begin{array}{l}-0.0231 \\
(0.0415)\end{array}$ & $\begin{array}{l}-0.00649 \\
(0.0574)\end{array}$ & $\begin{array}{l}-0.0477 \\
(0.0902)\end{array}$ \\
\hline$\Delta$ Short-term interest rate & $\begin{array}{l}0.00227 \\
(0.0208)\end{array}$ & $\begin{array}{c}0.0296 \\
(0.0193)\end{array}$ & $\begin{array}{l}-0.0282 \\
(0.0287)\end{array}$ & $\begin{array}{l}-0.0233 \\
(0.0282)\end{array}$ & $\begin{array}{l}-0.0197 \\
(0.0375)\end{array}$ & $\begin{array}{l}-0.0846 \\
(0.0541)\end{array}$ \\
\hline VIX & $\begin{array}{l}-0.0288^{*} \\
(0.0154)\end{array}$ & $\begin{array}{c}-0.0102 \\
(0.00871)\end{array}$ & $\begin{array}{c}-0.0618^{* * *} \\
(0.0181)\end{array}$ & $\begin{array}{c}-0.0417 * * \\
(0.0189)\end{array}$ & $\begin{array}{c}-0.0540 * * \\
(0.0274)\end{array}$ & $\begin{array}{c}-0.0966^{* *} \\
(0.0385)\end{array}$ \\
\hline Constant & $\begin{array}{c}6.638 * * * \\
(0.322)\end{array}$ & $\begin{array}{c}6.030 * * * \\
(0.257)\end{array}$ & $\begin{array}{c}7.978 * * * \\
(0.649)\end{array}$ & $\begin{array}{c}4.671 * * * \\
(0.641)\end{array}$ & $\begin{array}{c}4.583 * * * \\
(1.119)\end{array}$ & $\begin{array}{c}6.969 * * * \\
(0.861)\end{array}$ \\
\hline Observations & 10,579 & 1,381 & 2,081 & 1,789 & 837 & 1,482 \\
\hline R-squared & 0.433 & 0.831 & 0.667 & 0.571 & 0.792 & 0.745 \\
\hline USD Debt Proportion & $<1.5 \%$ & {$[1.5 \%, 4.5 \%]$} & $\begin{array}{l}(4.5 \% \\
10.8 \%]\end{array}$ & $\begin{array}{l}(10.8 \%, \\
20.3 \%]\end{array}$ & $(23.6,35.9]$ & $>35.9 \%$ \\
\hline Firm FE & Yes & Yes & Yes & Yes & Yes & Yes \\
\hline
\end{tabular}


Table 11. Investment-Real Exchange Rate

\begin{tabular}{|c|c|c|c|c|c|}
\hline VARIABLES & $\begin{array}{l}\text { (1) } \\
\text { Investment }\end{array}$ & $\begin{array}{l}\text { (2) } \\
\text { Investment }\end{array}$ & $\begin{array}{l}\text { (3) } \\
\text { Investment }\end{array}$ & $\begin{array}{l}\text { (4) } \\
\text { Investment }\end{array}$ & $\begin{array}{l}\text { (5) } \\
\text { Investment }\end{array}$ \\
\hline U.S. dollar Debt Portion & $\begin{array}{l}-0.000385 \\
(0.00140)\end{array}$ & $\begin{array}{l}-0.00195 \\
(0.00157)\end{array}$ & $\begin{array}{l}-0.00191 \\
(0.00156)\end{array}$ & $\begin{array}{l}-0.00175 \\
(0.00159)\end{array}$ & $\begin{array}{l}-0.00197 \\
(0.00160)\end{array}$ \\
\hline$\Delta$ Real Exchange Rate & $\begin{array}{l}-0.0379 * * \\
(0.0166)\end{array}$ & $\begin{array}{l}-0.0462 * * * \\
(0.0170)\end{array}$ & $\begin{array}{l}-0.0492 * * * \\
(0.0170)\end{array}$ & $\begin{array}{l}-0.0502 * * * \\
(0.0173)\end{array}$ & $\begin{array}{l}-0.0579 * * * \\
(0.0178)\end{array}$ \\
\hline U.S. dollar Debt Portion* $\Delta$ Real Exchange Rate & & $\begin{array}{l}0.0375^{* *} \\
(0.0167)\end{array}$ & $\begin{array}{l}0.0378 * * \\
(0.0167)\end{array}$ & $\begin{array}{l}0.0353 * * \\
(0.0169)\end{array}$ & $\begin{array}{l}0.0377 * * \\
(0.0170)\end{array}$ \\
\hline Leverage & & & $\begin{array}{l}-0.00532 * * * \\
(0.000988)\end{array}$ & $\begin{array}{l}-0.00523 * * * \\
(0.00103)\end{array}$ & $\begin{array}{l}-0.00505 * * * \\
(0.00105)\end{array}$ \\
\hline Tobin's Q & & & & $\begin{array}{l}0.0120 * * * \\
(0.00106)\end{array}$ & $\begin{array}{l}0.0116^{* * *} \\
(0.00108)\end{array}$ \\
\hline Cash & & & & & $\begin{array}{l}0.0682 * * * \\
(0.0215)\end{array}$ \\
\hline$\Delta$ Short-term Interest Rate & $\begin{array}{l}0.000459 \\
(0.000340)\end{array}$ & $\begin{array}{l}0.000459 \\
(0.000340)\end{array}$ & $\begin{array}{l}0.000482 \\
(0.000340)\end{array}$ & $\begin{array}{l}0.000430 \\
(0.000363)\end{array}$ & $\begin{array}{l}0.000388 \\
(0.000367)\end{array}$ \\
\hline Constant & $\begin{array}{l}0.0768 * * * \\
(0.00129)\end{array}$ & $\begin{array}{l}0.0770 * * * \\
(0.00129)\end{array}$ & $\begin{array}{l}0.0823 * * * \\
(0.00162)\end{array}$ & $\begin{array}{l}0.0683 * * * \\
(0.00202)\end{array}$ & $\begin{array}{l}0.0632 * * * \\
(0.00256)\end{array}$ \\
\hline Observations & 19,202 & 19,202 & 19,202 & 18,395 & 17,527 \\
\hline R-squared & 0.166 & 0.166 & 0.168 & 0.163 & 0.163 \\
\hline Firm FE & Yes & Yes & Yes & Yes & Yes \\
\hline
\end{tabular}

Standard errors in parentheses

$* * * \mathrm{p}<0.01, * * \mathrm{p}<0.05, * \mathrm{p}<0.1$

This table uses the sub-sample of firms which we have concrete measures of firms' USD debt proportion, there are in total 1420 firms in our samle covering both tradable industries and non-tradable industries. Investment is the capital expenditure divided by lagged total assets; leverage is total debt divided by lagged total assets, cash is cash holding divided by lagged total assets. Tobin's Q is total market value of firm diveded by total book value of firm and then lagged by one period. USD debt portion is (U.S. dollar loan+U.S. dollar bond)*Exchange Rate/Total Asset. 
Table 12. Investment-Nominal Exchange Rate

\begin{tabular}{|c|c|c|c|c|c|}
\hline VARIABLES & $\begin{array}{l}1) \\
\text { Investment }\end{array}$ & $\begin{array}{l}\text { (2) } \\
\text { Investment }\end{array}$ & $\begin{array}{l}\text { (3) } \\
\text { Investment }\end{array}$ & $\begin{array}{l}\text { (4) } \\
\text { Investment }\end{array}$ & $\begin{array}{l}\text { (5) } \\
\text { Investment }\end{array}$ \\
\hline U.S. dollar Debt Portion & $\begin{array}{l}-0.000309 \\
(0.00138)\end{array}$ & $\begin{array}{l}-0.000394 \\
(0.00140)\end{array}$ & $\begin{array}{l}-0.00110 \\
(0.00144)\end{array}$ & $\begin{array}{l}-0.000956 \\
(0.00146)\end{array}$ & $\begin{array}{l}-0.00109 \\
(0.00147)\end{array}$ \\
\hline$\Delta$ Nominal Exchange Rate & $\begin{array}{l}-0.0257 \\
(0.0167)\end{array}$ & $\begin{array}{l}-0.0281 * \\
(0.0169)\end{array}$ & $\begin{array}{l}-0.0357 * * \\
(0.0172)\end{array}$ & $\begin{array}{l}-0.0458 * * * \\
(0.0175)\end{array}$ & $\begin{array}{l}-0.0520 * * * \\
(0.0181)\end{array}$ \\
\hline $\begin{array}{l}\text { U.S. dollar Debt Portion* } \Delta \\
\text { Nominal Exchange Rate }\end{array}$ & & & $0.0312 * *$ & $0.0297 * *$ & $0.0307 * *$ \\
\hline & & & $(0.0151)$ & $(0.0152)$ & $(0.0153)$ \\
\hline Leverage & & & & $\begin{array}{l}-0.00526 * * * \\
(0.00103)\end{array}$ & $\begin{array}{l}-0.00509 * * * \\
(0.00105)\end{array}$ \\
\hline Tobin's Q & & & & $\begin{array}{l}0.0120 * * * \\
(0.00106)\end{array}$ & $\begin{array}{l}0.0117 * * * \\
(0.00108)\end{array}$ \\
\hline Cash & & & & & $\begin{array}{l}0.0672 * * * \\
(0.0215)\end{array}$ \\
\hline$\Delta$ Short-term Interest Rate & & $\begin{array}{l}0.000470 \\
(0.000340)\end{array}$ & $\begin{array}{l}0.000472 \\
(0.000340)\end{array}$ & $\begin{array}{l}0.000440 \\
(0.000363)\end{array}$ & $\begin{array}{l}0.000401 \\
(0.000367)\end{array}$ \\
\hline Constant & $\begin{array}{l}0.0765 * * * \\
(0.00125)\end{array}$ & $\begin{array}{l}0.0764 * * * \\
(0.00130)\end{array}$ & $\begin{array}{l}0.0765 * * * \\
(0.00130)\end{array}$ & $\begin{array}{l}0.0677 * * * \\
(0.00202)\end{array}$ & $\begin{array}{l}0.0626 * * * \\
(0.00256)\end{array}$ \\
\hline Observations & 19,960 & 19,202 & 19,202 & 18,395 & 17,527 \\
\hline R-squared & 0.157 & 0.166 & 0.166 & 0.163 & 0.163 \\
\hline Firm FE & Yes & Yes & Yes & Yes & Yes \\
\hline
\end{tabular}

Standard errors in parentheses

$$
* * * \mathrm{p}<0.01, * * \mathrm{p}<0.05, * \mathrm{p}<0.1
$$

This table uses the sub-sample of firms which we have concrete measures of firms' USD debt proportion, there are in total 1420 firms in our samle covering both tradable industries and non-tradable industries. Investment is the capital expenditure divided by lagged total assets; leverage is total debt divided by lagged total assets, cash is cash holding divided by lagged total assets. Tobin's Q is total market value of firm diveded by total book value of firm and then lagged by one period. USD debt portion is (U.S. dollar loan+U.S. dollar bond)*Exchange Rate/Total Asset. 
Table 13. Investment-Quantile Refressions

\begin{tabular}{|c|c|c|c|c|c|c|}
\hline VARIABLES & $\begin{array}{c}(1) \\
\text { CAPEX }\end{array}$ & $\begin{array}{c}(2) \\
\text { CAPEX } \\
\end{array}$ & $\begin{array}{c}(3) \\
\text { CAPEX }\end{array}$ & $\begin{array}{c}(4) \\
\text { CAPEX }\end{array}$ & $\begin{array}{c}(5) \\
\text { CAPEX } \\
\end{array}$ & $\begin{array}{c}(6) \\
\text { CAPEX }\end{array}$ \\
\hline USD debt portion & $\begin{array}{c}1.207 \\
(1.253)\end{array}$ & $\begin{array}{c}0.159 \\
(0.238)\end{array}$ & $\begin{array}{l}0.257^{*} \\
(0.134)\end{array}$ & $\begin{array}{c}0.0328 \\
(0.0957)\end{array}$ & $\begin{array}{l}-0.166 \\
(0.159)\end{array}$ & $\begin{array}{l}-0.640 \\
(0.561)\end{array}$ \\
\hline$\Delta$ Nominal Exchange Rate & $\begin{array}{c}-0.0638 * * \\
(0.0318)\end{array}$ & $\begin{array}{c}-0.0590 * * \\
(0.0243)\end{array}$ & $\begin{array}{c}-0.0724 * * \\
(0.0298)\end{array}$ & $\begin{array}{c}0.0408 \\
(0.0396)\end{array}$ & $\begin{array}{c}0.0107 * \\
(0.00504)\end{array}$ & $\begin{array}{l}0.0243 * * \\
(0.00841)\end{array}$ \\
\hline Leverage & $\begin{array}{c}-0.00440^{* *} \\
(0.00171)\end{array}$ & $\begin{array}{c}-0.00629 * * * \\
(0.00162)\end{array}$ & $\begin{array}{c}-0.0118 * * * \\
(0.00220)\end{array}$ & $\begin{array}{c}-0.00425^{* *} \\
(0.00215)\end{array}$ & $\begin{array}{c}-0.0129 * * * \\
(0.00422)\end{array}$ & $\begin{array}{c}-0.00851 * * * \\
(0.00210)\end{array}$ \\
\hline Tobin's Q & $0.00870 * * *$ & $0.0316^{* * *}$ & $0.0392 * * *$ & $0.0437 * * *$ & $0.0476^{* * *}$ & $0.0319 * * *$ \\
\hline Cash & $\begin{array}{c}(0.00141) \\
0.0744 * * \\
(0.0332)\end{array}$ & $\begin{array}{c}(0.00399) \\
0.0586 \\
(0.0442)\end{array}$ & $\begin{array}{c}(0.00473) \\
0.0834 * \\
(0.0455)\end{array}$ & $\begin{array}{l}(0.00545) \\
0.153 * * * \\
(0.0483)\end{array}$ & $\begin{array}{c}(0.00788) \\
0.0754 \\
(0.0842)\end{array}$ & $\begin{array}{c}(0.00460) \\
0.0562 \\
(0.0602)\end{array}$ \\
\hline Constant & $\begin{array}{c}0.0582 * * * \\
(0.00389)\end{array}$ & $\begin{array}{c}0.0413 * * * \\
(0.00882)\end{array}$ & $\begin{array}{c}0.0335 * * * \\
(0.0116)\end{array}$ & $\begin{array}{l}0.0291 * \\
(0.0158)\end{array}$ & $\begin{array}{l}0.00367 \\
(0.0403)\end{array}$ & $\begin{array}{c}0.0598 * * * \\
(0.00793)\end{array}$ \\
\hline $\begin{array}{l}\text { Observations } \\
\text { R-squared } \\
\text { USD Debt Proportion }\end{array}$ & $\begin{array}{c}10,579 \\
0.157 \\
<=1.5 \%\end{array}$ & $\begin{array}{c}1,381 \\
0.707 \\
(1.5 \%, 4.5 \%]\end{array}$ & $\begin{array}{c}2,081 \\
0.653 \\
(4.5 \%, 10.8 \%]\end{array}$ & $\begin{array}{c}1,789 \\
0.639 \\
(10.8 \% \\
20.3 \%]\end{array}$ & $\begin{array}{c}837 \\
0.681 \\
(20.3,35.9]\end{array}$ & $\begin{array}{c}1,482 \\
0.526 \\
>35.9 \%\end{array}$ \\
\hline Firm FE & Yes & Yes & Yes & Yes & Yes & Yes \\
\hline
\end{tabular}


Table 14. Investment:Exporters v.s. Non-exporters

\begin{tabular}{|c|c|c|c|c|}
\hline VARIABLES & $\begin{array}{l}(1) \\
\text { Investment }\end{array}$ & $\begin{array}{l}\text { (2) } \\
\text { Investment }\end{array}$ & $\begin{array}{l}\text { (3) } \\
\text { Investment }\end{array}$ & $\begin{array}{l}\text { (4) } \\
\text { Investment }\end{array}$ \\
\hline U.S. dollar Debt Portion & $\begin{array}{l}-0.00250 \\
(0.00186)\end{array}$ & $\begin{array}{l}0.0201 * * \\
(0.0102)\end{array}$ & $\begin{array}{l}-0.00202 \\
(0.00178)\end{array}$ & $\begin{array}{l}0.0215 * * \\
(0.0104)\end{array}$ \\
\hline$\Delta$ Real Exchange Rate & $\begin{array}{l}-0.0427 \\
(0.0260)\end{array}$ & $\begin{array}{l}-0.0303 * * \\
(0.0124)\end{array}$ & & \\
\hline U.S. dollar Debt Portion* $\Delta$ Real Exchange Rate & $\begin{array}{l}0.0375^{* *} \\
(0.0181)\end{array}$ & $\begin{array}{l}0.0319 \\
(0.0442)\end{array}$ & & \\
\hline$\Delta$ Nominal Exchange Rate & & & $\begin{array}{l}-0.0390 * \\
(0.0226)\end{array}$ & $\begin{array}{l}-0.0388^{*} \\
(0.0203)\end{array}$ \\
\hline U.S. dollar Debt Portion* $\Delta$ Nominal Exchange Rate & & & $\begin{array}{l}0.0331 * * \\
(0.0166)\end{array}$ & $\begin{array}{l}0.0469 \\
(0.0403)\end{array}$ \\
\hline Leverage & $\begin{array}{l}-0.00547 * * * \\
(0.00125)\end{array}$ & $\begin{array}{l}-0.00626^{* * *} \\
(0.00117)\end{array}$ & $\begin{array}{l}-0.00548 * * * \\
(0.00125)\end{array}$ & $\begin{array}{l}-0.00633 * * * \\
(0.00118)\end{array}$ \\
\hline Tobin's Q & $\begin{array}{l}0.0165 * * * \\
(0.00141)\end{array}$ & $\begin{array}{l}0.00331 * * * \\
(0.00104)\end{array}$ & $\begin{array}{l}0.0166 * * * \\
(0.00141)\end{array}$ & $\begin{array}{l}0.00331 * * * \\
(0.00104)\end{array}$ \\
\hline Cash & $\begin{array}{l}0.0605^{* *} \\
(0.0236)\end{array}$ & $\begin{array}{l}0.120^{* *} \\
(0.0476)\end{array}$ & $\begin{array}{l}0.0598 * * \\
(0.0236)\end{array}$ & $\begin{array}{l}0.119 * * \\
(0.0476)\end{array}$ \\
\hline Constant & $\begin{array}{l}0.0570 * * * \\
(0.00298)\end{array}$ & $\begin{array}{l}0.0854 * * * \\
(0.00339)\end{array}$ & $\begin{array}{l}0.0565 * * * \\
(0.00298)\end{array}$ & $\begin{array}{l}0.0846^{* * *} \\
(0.00339)\end{array}$ \\
\hline Observations & 13,528 & 4,621 & 13,528 & 4,621 \\
\hline R-squared & 0.157 & 0.397 & 0.157 & 0.398 \\
\hline Firm FE & Yes & Yes & Yes & Yes \\
\hline Exporter & No & Yes & No & Yes \\
\hline
\end{tabular}

Standard errors in parentheses;
$* * * \mathrm{p}<0.01, * * \mathrm{p}<0.05, * \mathrm{p}<0.1$

This table uses the sub-sample of firms which we have concrete measures of firms' USD debt proportion, there are in total 1420 firms in our samle covering both tradable industries and non-tradable industries. The regression furthre divided into the exportor firms and non-exportor firms. A firm is defined as exportor if it has ever had export income shown up in its balancesheet in its operating history. Investment is the capital expenditure divided by lagged total assets; leverage is total debt divided by lagged total assets, cash is cash holding divided by lagged total assets. Tobin's $Q$ is total market value of firm diveded by total book value of firm and then lagged by one period. USD debt portion is (U.S. dollar loan+U.S. dollar bond)*Exchange Rate/Total Asset. 